University of Rhode Island

DigitalCommons@URI

Open Access Master's Theses

1997

\title{
Distribution of Quahog Larvae Along a North-South Transect in Narragansett Bay
}

Nurlisa A. Butet

University of Rhode Island

Follow this and additional works at: https://digitalcommons.uri.edu/theses

\section{Recommended Citation}

Butet, Nurlisa A., "Distribution of Quahog Larvae Along a North-South Transect in Narragansett Bay" (1997). Open Access Master's Theses. Paper 1.

https://digitalcommons.uri.edu/theses/1

This Thesis is brought to you for free and open access by DigitalCommons@URI. It has been accepted for inclusion in Open Access Master's Theses by an authorized administrator of DigitalCommons@URI. For more information, please contact digitalcommons-group@uri.edu. 


\section{DISTRIBUTION OF QUAHOG LARVAE \\ ALONG A NORTH - SOUTH TRANSECT \\ IN NARRAGANSETT BAY}

BY

NURLISA A. BUTET

A THESIS SUBMITTED IN PARTIAL FULFILLMENT OF THE REQUIREMENTS FOR THE DEGREE OF MASTER OF SCIENCE

IN

FISHERIES, ANIMAL, AND VETERINARY SCIENCE 


\section{MASTER OF SCIENCE THESIS \\ OF}

NURLISA A. BUTET

APPROVED :

Thesis Committee

Major Professor
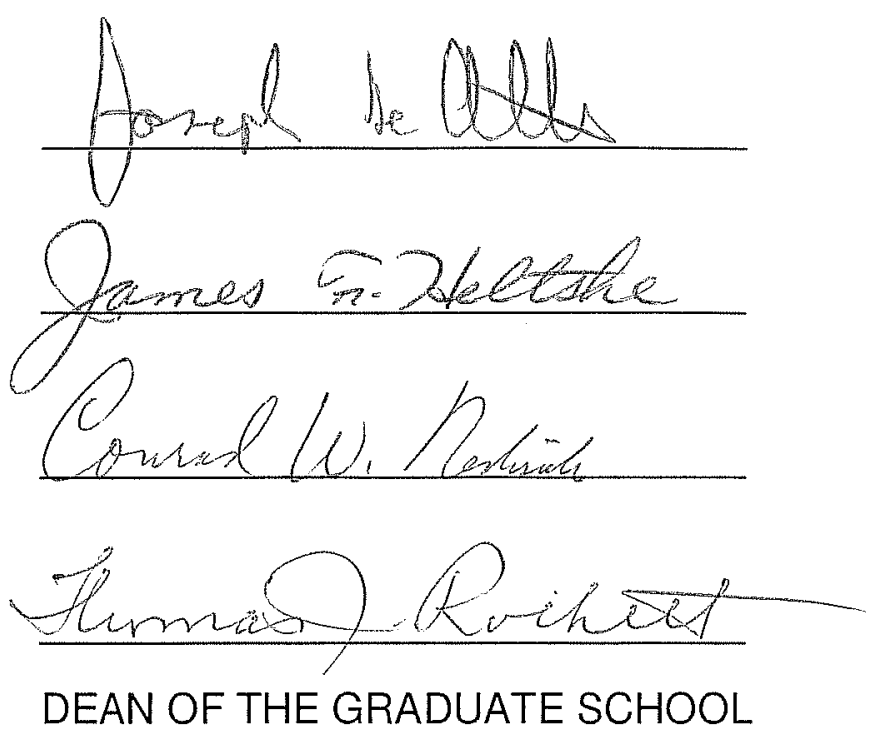

UNIVERSITY OF RHODE ISLAND 


\section{ABSTRACT}

A study on the distribution of quahog (Mercenaria mercenaria (Linnaeus 1758)) larvae in Narragansett Bay, Rhode Island was conducted during a single summer season in 1995. Samples of the larvae were collected weekly using an electric bilge pump and a $60 \mu \mathrm{m}$ mesh plankton net at two depths $(0.3 \mathrm{~m}$ and 1.6 m) at five sampling stations distributed landward along the West shore, $12.6 \mathrm{~km}$ to $30.6 \mathrm{~km}$ from Rhode Island Sound. Three stations were located in the upper estuary, i.e., Upper Bay, and two stations were in the lower estuary, i.e., Upper West Passage.

The temporal distribution of quahog larvae was consistent with moon phase; more larvae were found during neap tides. Early stage larvae, i.e., Dhinge veligers at the age of 1-3 days occurred weekly throughout the period of sample collection and reached peak abundance on June 20. In contrast to the constant occurrence of early stage larvae, late stage larvae, i.e., umbonate veligers, were sometimes absent in the plankton samples. The late stage larvae reached peak abundance on July 7 at all but one station. On the basis of the peak abundances of the two developmental stages, I confirm that the duration of planktonic life of quahog larvae is about 2-3 weeks. Due to high abundances of late stage larvae during this period, the highest intensity of settlement probably occurs in Narragansett Bay around mid July. There was a tendency for a different distributional pattern between the larvae collected from Upper Bay and Upper West Passage stations.

Densities of quahog larvae decreased away from the major spawner stock area (Providence River) probably due to the effect of tidal and non-tidal currents and turbulent diffusion. Tidal excursions of $1-4.4 \mathrm{~km}$ could be responsible for displacing the larvae from the Providence River into as far as Upper Bay in one 
ebb tide. It is probable that small numbers of larvae might be transported into Upper West Passage due to non-tidal currents. It appears that Upper Bay stations are the areas with relatively higher larval retention than other parts of the Bay.

Multiple linear regression analysis indicated that only $20 \%$ of the total variability of quahog larval densities in Narragansett Bay is explained by the independent variables, i.e., sampling depths, moon phase, water temperature and station location. 


\section{ACKNOWLEDGMENTS}

I would like to thank Dr. Michael Rice for proposing the topic, training me in computer image analysis, and showing me the ropes during the course of my study. Special thanks are due to Dr. Joseph DeAlteris who provided a thorough review, served as my major advisor during Dr. Rice's sabbatical, and provided me with the Boston Whaler. I am grateful to Dr. Conrad Recksiek for his advice during my stay in the Fisheries Department and for his invaluable comments on this manuscript. I would also like to thank Dr. James Heltshe for his suggestions on statistical analyses, Dr. Richard Wolke who gave me a space in his laboratory during the course of larval identification, and Dr. Dennis Nixon who served as the defense chairman.

I must express my deep appreciation for the support of my friends : Neil Thompson for helping me with sample collection and teaching me to operate the Boston Whaler, and Joe Goncalo for sharing his thoughts on the identification of the bivalve larvae.

This study would not have been accomplished without the financial support from Environmental Study Center - Development Project of the Government of the Republic of Indonesia.

My special gratitude to my husband for his love and support which kept me going.

Finally, I dedicate this work to my late parents who kept encouraging me to study. 
Abstract

Page

Introduction

ii

Statement of Problem

Literature Review

Hypotheses

Materials and Methods 9

Study Area 9

Field Sampling 10

Laboratory Analyses 11

Enumeration of Larvae

Estimation of Mortality Rate 12

Statistical Analyses

12

Results

Physical Environment

Distribution of Larvae

Mortality

Statistical Analyses

Discussion

69

Distribution of Quahog Larvae 69

Mortality 75

Statistical Analyses 76

Summary 77

Appendix 78

Bibliography 79 


\section{LIST OF TABLES}

Page

Table 1. Temperature $\left({ }^{\circ} \mathrm{C}\right)$ and salinity (ppt) at five sampling stations in Narragansett Bay during the summer 1995. T, temperature; S, salinity; N/A, data not available; Numbers in parentheses denote Julian day.

Table 2. Densities of quahog larvae (per $100 \mathrm{I}$ ) at two sampling depths in five stations of Narragansett Bay during summer 1995. T, total larvae; E, early stage larvae (see text); L, late stage larvae (see text); N/A, data not available; Numbers in parentheses denote Julian day.

Table 3. Densities of other bivalve larvae (per $100 \mathrm{I}$ ) at two sampling depths in five stations of Narragansett Bay during summer 1995. T, total larvae; E, early stage larvae (see text); L, late stage larvae (see text); N/A, data not available; Numbers in parentheses denote Julian day.

Table 4. Rate of mortality of quahog larvae in Narragansett Bay during summer 1995. Cohort is defined as a group of larvae at an early stage developing into the late stage within $11-17$ days.

Table 5. Non-parametric procedure to determine whether there is a difference between abundances of quahog larvae during neap (N.T) and spring (S.T) tides in Narragansett Bay in the summer of 1995.

Table 6. Non-parametric test, using Kruskal-Wallis method, to determine whether there are differences of quahog larval abundances among five stations. 
Table 7. Non-parametric procedure to determine whether there is a difference between abundances of quahog larvae at two depths $(0.3 \mathrm{~m}$ and $1.6 \mathrm{~m})$ in Narragansett Bay during summer 1995.

Table 8. Result of multiple regression, x1, depth; x2, moon phase; $x 3$, temperature; $x 4-x 7$, station.

Table 9. Result of stepwise method, variable moon phase entered.

Table 10. Result of stepwise method, variable stations entered. $x 1$, moon phase; $x 2-x 5$, stations. 


\section{LIST OF FIGURES}

Figure 1. Map of Narragansett Bay showing five sampling stations. CP, Conimicut Pt.; RP, Rocky Pt.; WP, Warwick Pt.; MV, Mt. View; W, Wickford.

Figure 2. Distribution of bivalve larvae at early stage associated with temperature in Conimicut Pt. —- : temperature; - - : quahog larvae; + : other bivalve larvae; - - : total bivalve larvae.

Figure 3. Distribution of bivalve larvae at late stage associated with temperature in Conimicut Pt. —- : temperature; — quahog larvae; + : other bivalve larvae; - - : total bivalve larvae.

Figure 4. Distribution of bivalve larvae at early stage associated with temperature in Rocky Pt. — : : temperature; — — : quahog larvae; + : other bivalve larvae; - - : total bivalve larvae.

Figure 5. Distribution of bivalve larvae at late stage associated with temperature in Rocky Pt. —- : temperature; —- : quahog larvae; + : other bivalve larvae; - - : total bivalve larvae.

Figure 6. Distribution of bivalve larvae at early stage associated with temperature in Warwick Pt. - - : temperature; - - : quahog larvae; + : other bivalve larvae; $-\longrightarrow$ : total bivalve larvae.

Figure 7. Distribution of bivalve larvae at late stage associated with temperature in Warwick Pt. —- : temperature; —- : quahog larvae; + : other bivalve larvae; $\longrightarrow-$ : total bivalve larvae.

Figure 8. Distribution of bivalve larvae at early stage associated with temperature in Mt. View. ——: temperature; - - : quahog larvae; + : other bivalve larvae; - - : total bivalve larvae. 
Figure 9. Distribution of bivalve larvae at late stage associated with temperature in Mt. View. —-: temperature; ——: quahog larvae; + : other bivalve larvae; - - : total bivalve larvae.

Figure 10. Distribution of bivalve larvae at early stage associated with temperature in Wickford. - - temperature; - - : quahog larvae; + : other bivalve larvae; - - : total bivalve larvae.

Figure 11. Distribution of bivalve larvae at late stage associated with temperature in Wickford. : temperature; - - : quahog larvae; + : other bivalve larvae; - - : total bivalve larvae.

Figure 12. Distribution of bivalve larvae associated with moon phase in Narragansett Bay. — quahog larvae; - other bivalve larvae; - - : total bivalve larvae.

Figure 13. Relationship between abundance of quahog larvae and water temperature at Conimicut Pt. during summer 1995

Figure 14. Relationship between abundance of quahog larvae and water temperature at Rocky Pt. during summer 1995

Figure 15. Relationship between abundance of quahog larvae and water temperature at Warwick Pt. during summer 1995

Figure 16. Relationship between abundance of quahog larvae and water temperature at Mt. View during summer 1995

Figure 17. Relationship between abundance of quahog larvae and water temperature at Wickford during summer 1995 


\section{INTRODUCTION}

\section{Statement of Problem}

The quahog (Mercenaria mercenaria) fishery in Rhode Island is of major economic importance. It is considered to be the largest inshore fishery within the state (Pratt, 1988; Lazar et al., 1995). The fishery began in pre-colonial times (Rice, 1996), and has gradually become more important following the decline of the oyster fishery between 1930s and 1950s, primarily due to pollution (Pratt, 1988; Bean, 1990). The commercial landings of quahogs depend almost entirely upon the stock in Narragansett Bay (Lazar et al., 1995; Rice and Goncalo, 1995), the principal estuary in the state of Rhode Island. The harvest reached a peak of 5 million pounds in 1955, after which catch declined (Lazar et al., 1995). A second peak of 4 million pounds occurred in 1983. However, commercial landings in 1994 ranked second to Connecticut among other states in New England (Rice, 1996).

The harvestable quahog stocks in Narragansett Bay are not distributed uniformly (Pratt, 1988). There is a tendency of decreasing numbers from upper to lower estuary (Pratt, 1988). In the upper estuary, the Providence River area and Upper Bay (Figure 1), which are prohibited areas for shellfishing (Bean, 1990), have the highest densities of adult quahogs, and these quahogs constitute a potential spawning stock (Pratt, 1988). In contrast, the West Passage in the lower estuary, an open area for shellfishing (Bean, 1990) has a much lower quahog density (Rice, 1993).

Despite many studies focusing on the adult quahog populations (Stickney and Stringer, 1957; Saila et al., 1967; Jones et al., 1989; Rice et al., 1989), there have been few studies on quahog larvae in Narragansett Bay. Landers (1954) 
Figure 1. Map of Narragansett Bay showing five sampling stations. CP, Conimicut Pt.; RP, Rocky Pt.; WP, Warwick Pt.; MV, Mt. View; W, Wickford. 


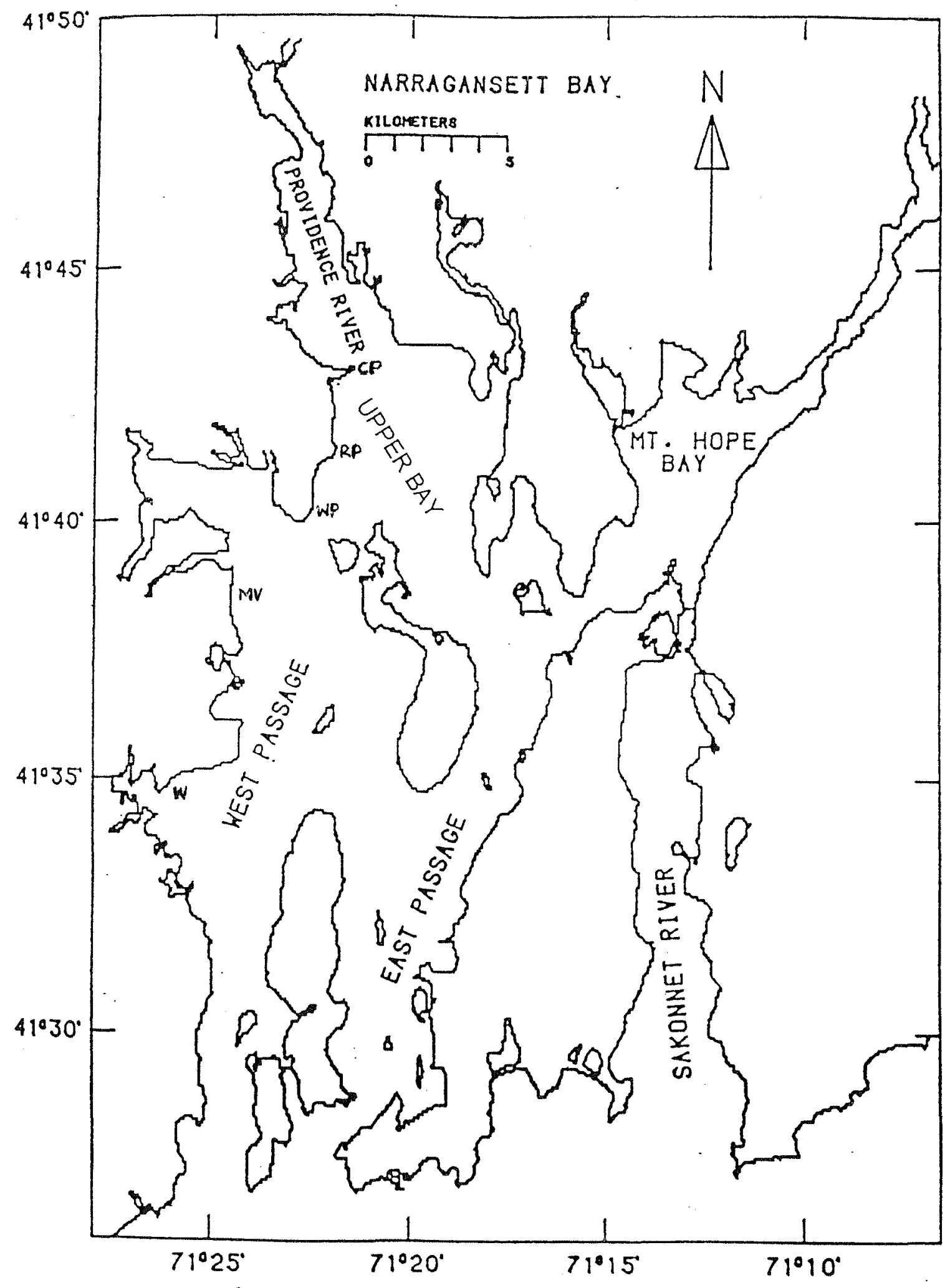


studied the abundance of bivalve larvae - assuming them to be quahog during three consecutive years $(1950,1951$, and 1952) at two Narragansett Bay sites, in Greenwich Bay and off Wickford (Figure 1). No other study directed attention at the distribution of bivalve larvae in Narragansett Bay for about 40 years, until Rice and Goncalo in 1993 conducted their study at seven stations in Greenwich Bay. Therefore, to establish a better understanding of the ecology of early life stages of quahogs, this study attempts to describe patterns of quahog larval distribution in the western part of Narragansett Bay.

\section{Literature Review}

The northern quahog is a filter feeder inhabiting shallow coastal waters from the Gulf of St. Lawrence in Canada to Florida (Rice, 1992). Like many other bivalves, young quahogs are typically males. In successive years they may change sex and produce eggs, a characteristic called protandric hermaphrodism (Rice, 1992). Both eggs and sperm of adults are expelled in the water column, thus, fertilization proceeds externally (Rice, 1992). Spawning normally begins in the late spring as water temperature increases (Menzel, 1989; Rice, 1992), and it lasts into the summer months (Bricelj, 1993; Rice 1993). Therefore, the existence of the larvae of quahog in the water column is considered temperature - dependent.

Larval quahogs pass through a series of well-defined, recognizable stages characterized by appearance and dimension (Carriker, 1961; Loosanoff et al., 1966; Chanley and Andrews, 1971). According to Carriker (1961), by 12 hours after fertilization, a fertilized egg becomes a planktonic trochopore larva. The shape of this larva is oval; it has a dense mat of long cilia over the equatorial region. At an age of 1 - 3 days, a velum develops to facilitate 
swimming. At this stage, a $90-140 \mu \mathrm{m}$ straight-hinge is formed at the dorsal section of the valves. Thus, it is called a straight-hinged veliger or early stage larva. At a valve length of $140-220 \mu \mathrm{m}$, or at an age as early as three days, the larva develops into an umbonate stage or late stage larva in which the umbo rises slightly above the hinge line. At six days the larva develops a foot and enters pediveliger stage where the valve length is $170-220 \mu \mathrm{m}$; the velum is still present. Both foot and velum facilitate finding a suitable substrate for settlement and metamorphosis.

Early stage bivalve larvae in St. Mary's River, Maryland (Manning and Whaley, 1954) and Greenwich Bay, Rhode Island (Rice and Goncalo, 1995) tended to remain in the upper water column, while late stage larvae stayed close to or on the bottom. The difference in depth distribution may be a function of stage - dependent specific gravity of the larvae. Younger larvae have lower specific gravity than seawater; the specific gravity of the older larvae is greater (Manning and Whaley, 1954). Rice and Goncalo (1995) speculated that the effect of light was responsible for depth distribution; early stage larvae were considered positively phototactic as they occurred near the surface, while late stage larvae were considered negatively phototactic because they occurred away from the surface.

According to Wood and Hargis (1971) the selective swimming process (i.e., sinking and rising throughout the tidal cycle) within the water column is stimulated by tides. The late stage bivalve larvae in a New Jersey estuary dropped on or close to the bottom during the period of slack water and remained there through the falling salinities of ebbing tide. They were apparently stimulated to rise by the increasing salinity of early flooding tides (Carriker, 1951). In contrast, early stage larvae showed uniform vertical distribution throughout the tidal current cycle (Carriker, 1951; Kunkle, 1958). 
The ability of bivalve larvae to adjust their position vertically in the water column may provide the most important mechanism in controlling horizontal distribution (Ketchum, 1955; Kunkle, 1958; Wood and Hargis, 1971; Okubo, 1994; Samarco and Heron, 1994) and, ultimately, their recruitment success (McConaugha, 1988). Their horizontal displacement, like many other species having planktonic larvae, is subject to estuarine circulation (Sandifer, 1975) induced by tides (Carriker, 1955; Kunkle, 1958; Carriker, 1961; Seliger et al., 1982; Andrews, 1983), gravitational circulation (Ketchum, 1954; Wood and Hargis, 1971; Okubo, 1994), and wind (Manning and Whaley, 1954).

Larvae inhabiting upper water column during ebb tides can be dispersed seaward, and the densities were lower than those during flood tides (Carriker, 1961; Andrews, 1983). Nelson (1955) studied the distribution of oyster larvae in Barnegat Bay, New Jersey and found that the early stage larvae were carried as far as $3.4 \mathrm{~km}$ seaward from spawning beds. In order to maintain their existence in the estuary, the larvae should, therefore, swim bottomward during ebb tides as lower layer gravitational circulation may carry the larvae landward (Wood and Hargis, 1971; Sandifer, 1975).

On the studies of oyster larvae near Oösterschelde, Holland (Korringa, 1947) and quahog larvae in Little Egg Harbor, New Jersey (Carriker, 1961), those researchers found that major peak of larval abundance occurred 8 - 10 days after full or new moon, concomitant with neap tides. The abundance of the larvae showed minor peaks in the intervening periods.

Wind induced circulation is another influential factor on the dispersion of bivalve larvae, besides tidal circulation. Prevailing winds blowing from one direction may induce currents (Perkins, 1974), which produce a net - horizontal transport of water on the surface (Ippen, 1966; Perkins, 1974; Tett, 1987). In St. Mary's River estuary, Maryland, according to Manning and Whaley (1954), 
the pattern of longitudinal circulation is strongly influenced by prevailing southerly winds and provides a means of slow up-estuary transport and insures retention of the larvae in the upper estuary. The St. Mary's River is characterized by having low riverine discharge and high spatfalls on the upriver beds. Additionally, wind driven circulation has the potential for dispersing larvae from the spawning beds. In the Choptank River system, Maryland, prolonged down - estuary winds dilute out the retained larvae of two tributaries constituting major spawning areas, and carry the larvae downestuary (Seliger et al., 1982).

In respect to temporal distribution, Landers (1954), Carriker (1961), and Rice and Goncalo (1995) established the fact that the peak of bivalve larval abundances occurred as water temperature reached about $20^{\circ} \mathrm{C}$, as summer progresses. During three consecutive years $(1950,1951$, and 1952) of his study in Greenwich Bay and Wickford, Rhode Island, Landers found no consistent distributional pattern of quahog larvae from summer to summer. This may have been caused by variations in water temperature that stimulates spawning. Water temperature in 1950 was consistently lower than in either 1951 or 1952. This condition may explain the late beginning of spawning and occurrence of quahog larvae in that year. In spite of these variations, the population of quahog larvae at both sites reached the peak abundances in June as water temperature increased approximately to $19.0^{\circ} \mathrm{C}$. Carriker (1961) seemed to agree with Landers' opinion that variations of water temperature, in the course of his four successive year study, accounted for the variations of quahog larval abundance in Little Egg Harbor, New Jersey. However, in his study of oyster larvae near Oösterschelde, Holland, Korringa (1947) attempted to show but failed to prove that the peak of larval abundance depends upon water temperature. 
Additional knowledge of distribution and abundance of larvae might explain their ability to maintain adult bivalve populations within estuaries (Haven and Fritz, 1987). In this study I tested hypotheses designed to enhance knowledge of Narragansett Bay quahog populations.

\section{Hypotheses}

The hypotheses evaluated for early stage and late stage quahog larvae in this study are :

1. Daily water temperatures affect the temporal distribution of the larvae ;

2. Spring and neap tides affect the abundances of quahog larvae;

3. The abundance of quahog larvae vary spatially due to variations of adult quahog density;

4. Larval abundance varies between two sampling depths. 


\section{MATERIALS AND METHODS}

\section{$\underline{\text { Study Area }}$}

Narragansett Bay is a major estuary in Rhode Island; and considered as the largest one in southern New England (Figure 1). Its location is surrounded by four coastal areas : Long Island Sound, Block Island Sound, Rhode Island Sound, and Buzzard's Bay (Spaulding, 1987). This system "...is composed of three north-south interconnected passages : a) West Passage, b) East Passage and the Providence River, and c) the Sakonnet River..." (Hicks, 1959).

Narragansett Bay is $40 \mathrm{~km}$ in length (Gordon, 1982); the surface area, shoreline length, and mean water volume are about $328 \mathrm{~km}^{2}, 412.5 \mathrm{~km}$, and $2,724 \mathrm{~km}^{3}$, respectively (Chinman and Nixon, 1985; Spaulding, 1987). Mean water depth is $8.3 \mathrm{~m}$, however, the depth of East Passage tends to be greater by a factor of two to West Passage and Sakonet River (Spaulding, 1987). There are three major rivers discharging into Narragansett Bay : a) Blackstone River, b) Pawtuxet River, and c) Taunton River and Seekonk River (Spaulding, 1987). The first two rivers discharge into the Providence River, while the last one empties into Mount Hope Bay (Spaulding, 1987). The mean discharge of the Blackstone, Pawtuxet, and Taunton are 20,11 , and $19 \mathrm{~m}^{3} / \mathrm{s}$, respectively (Spaulding, 1987). The mean residence time of Narragansett Bay water is about 26 days (Pilson, 1985).

Circulation in Narragansett Bay is due mainly to strong tidal currents (Levine and Kenyon, 1975), with gravitational induced by horizontal pressure gradients and wind-driven currents superimposed (Hess, 1976). This estuary is classified as a partially-mixed estuary, which means that the halocline dissipates and salinity increases gradually from surface to bottom (Pilson, 1985). Salinity 
decreased from the entrance to the head of the Bay; $31 \mathrm{ppt}$ at the entrance, while at the head values in the range of 10-20 ppt (Hicks, 1959). A salinity difference of only 2 ppt from surface to bottom is common (Gordon and Spaulding, 1987). Temperature increased from the entrance to the head with the difference of about $3^{\circ} \mathrm{C}$ from surface to bottom (Hicks, 1959).

\section{Field sampling}

This study was conducted at five sampling stations in Narragansett Bay (Figure 1). A description of the sampling location is as folow. The most northerly station, Conimicut Pt. $\left(41^{\circ} 43^{\prime}\right)$, was located approximately $500 \mathrm{~m}$ southeast of Conimicut Point. The second station is Rocky Pt. $\left(41^{\circ} 41.5^{\prime}\right)$ which was about 500 $\mathrm{m}$ in front of Rocky Point amusement park shore. Warwick Pt. $\left(41^{\circ} 40.5^{\prime}\right)$, the third station, was located approximately $1 \mathrm{~km}$ northeast of Warwick neck. Those stations are situated on the Upper Bay. The last two stations, Mt. View $\left(41^{\circ} 38^{\prime}\right)$ which was about $4 \mathrm{~km}$ south of the mouth of Greenwich Bay and Wickford ( $41^{\circ}$ $\left.34.8^{\prime}\right)$ which was about $3 \mathrm{~km}$ off Wickford Cove are located on the Upper West Passage. Those five sampling stations were selected with regard to a declining trend of adult quahog densities from upper to lower estuary (Pratt, 1988; Kremer, 1975). The sampling was carried out every two days per week during summer of 1995, from May 26 to August 30. Due to strong winds and wave on particular days, samplings were postponed for safety reasons.

Water samples were collected haphazardly with respect to tides, using a 12 volt battery electric bilge pump, at two depths, $0.3 \mathrm{~m}$ and $1.6 \mathrm{~m}$, at each station, similar to the method of Landers (1954). Prior to sampling collections, the electric bilge pump flow rate was calibrated by counting the amount of time required for pumping a 100 liter of water sample. The water samples were then filtered with a 
$60 \mu \mathrm{m}$ mesh plankton net. Retained plankton samples were fixed with $95 \%$ ethanol. Both surface water temperature and salinity in each station were measured. Tides and tidal current charts (Spaulding et al., 1990) were used to provide an information on the height of tides and velocity of tidal currents at the sampling stations.

\section{Laboratory Analyses}

In the laboratory, retained plankton samples were transferred to $30 \mathrm{ml}$ mixture of $25 \%$ ethanol and $75 \%$ seawater. Three replicates of $1.0 \mathrm{ml}$ subsamples of the preserved plankton were pipeted into a Sedgewick Rafter counting chamber. These subsamples were observed and counted using a stereoscopic microscope. To assist the progress of the identification, larval dimensions such as total, height, and hinge length were measured by using an image analysis (Optimas 4.0 software). Shape and dimension of the larvae were compared with photomicrographs provided by Loosanoff et al. (1966) and Chanley and Andrews (1971). The quahog larvae were categorized into two developmental stages. The early stage or straight-hinge larvae were characterized by a length of the hinge at least half of the total length. The late stage or umbonate stage was characterized as having hinge less than half of the total length and umbo begins to form.

\section{Enumeration of Larvae}

Numbers of larvae per 100 liter water sample $(N)$ were calculated :

$$
\mathrm{N}=\mathrm{n} \times \mathrm{v}
$$


where $n=$ average number of larvae per $1.0 \mathrm{ml}$ subsample, and $v=$ volume of mixture $25 \%$ ethanol and $75 \%$ seawater $=30 \mathrm{ml}$.

\section{Estimation of Mortality Rate}

Rate of mortality of the quahog larvae was estimated by first calculating the rate of survival using the following method (Royce, 1984) :

$$
\mathrm{S}=\mathrm{N}_{\mathrm{t}+1} / \mathrm{N}_{\mathrm{t}}
$$

where $S=$ survival rate, $N_{t+1}=$ number of larvae at late stage, $N_{t}=$ number of larvae at early stage. A cohort, herein, was defined as a group of larvae at an early stage developing into the late stage within two weeks. Thus, rate of mortality (M) was obtained from :

$$
M=1-S
$$

\section{Statistical Analyses}

To investigate the relationship between larval abundance $(Y)$ and water temperature $(X)$, a linear correlation analysis was used.

$$
r=\frac{S_{x y}}{\sqrt{S_{x x}} \sqrt{S_{y y}}}
$$

where

$$
S_{x y}=\Sigma(x-\bar{x})(y-\bar{y}) ; S_{x x}=\Sigma(x-\bar{x})^{2} ; S_{y y}=\Sigma(y-\bar{y})^{2}
$$

In addition, a qualitative evaluation of the water temperature required to trigger quahog spawning in Narragansett Bay was made by comparing the temporal variation in temperature with the temporal variation in larval abundances. 
A Wilcoxon Rank-Sum Test was used to examine: (1) the abundances of quahog larvae during neap tides vs spring tides; (2) the abundances of quahog larvae at $0.3 \mathrm{~m}$ vs $1.6 \mathrm{~m}$ depths. The procedure is as follow :

1. Assign $\mathrm{H}_{\mathrm{O}}$ : the populations are identical. Populations, herein, were determined as larval abundances during neap tides vs during spring tides and larval abundances at $0.3 \mathrm{~m}$ vs $1.6 \mathrm{~m}$ depths.

2. Rank the combined value of $n=n A+n B$ observations in the increasing order of magnitude. Where $n=$ total number of observation, $n A=$ number of observation in which larval abundances in condition A (i.e., during neap tides, or at $0.3 \mathrm{~m}$ depths), $\mathrm{nB}=$ number of observation in which larval abundances in condition B (i.e., during spring tides, or at $1.6 \mathrm{~m}$ depth).

3. Find the rank sum $W_{A}$ of the first sample of population having smaller sum of the ranks.

4. Assign $\mathrm{H}_{1}$ : the populations are different ; then the rejection region $(R)$ at both tails of $W_{A}$ (lower and upper tails) having equal probabilities.

5. Assign $R: P=P\left[W_{A} \leq x^{\star}\right]=P\left[W_{A} \geq x\right]$.

Since the sample sizes were larger than 8 , the null distribution of the ranksum statistic is approximately normal and the Wilcoxon test can therefore be performed using the normal table (Johnson and Bhattacharya, 1992). Under $\mathrm{H}_{\mathrm{O}}$, the distribution of $W_{A}$ has

$$
\begin{gathered}
\text { mean }=1 / 2\left\{n_{A}\left(n_{A}+n_{B}+1\right)\right\}, \text { and variance }=\left\{n_{A} n_{B}\left(n_{A}+n_{B}+1\right)\right\} / 12 \\
Z=\left(W_{A}-\text { mean }\right) / \sqrt{\text { variance }}
\end{gathered}
$$

Therefore, the rejection region to be :

$R: \quad|z| \geq z_{\alpha / 2}$ 
To determine if the abundance of quahog larvae varies among stations due to variations of adult quahog, the Kruskal-Wallis method was used because there are more than two stations as independent variables. This test is based on the ranks of the observation.

1. $H_{0}: \mu_{1}=\ldots=\mu_{5}$. Where $\mu_{\mathrm{j}}$ is the mean of larval abundances in the given station.

2. $H_{1}: \mu_{1} \neq \ldots \neq \mu_{5}$

3. All observations are ranked from 1 to $\mathrm{n}$. Let $\mathrm{Ri}$ be the mean of the ranks for the ith factor level and R.. the overall mean rank.

4. Test statistic :

$$
X_{k W}^{2}=\left(\frac{12}{n(n+1)} \sum_{i=1}^{r} n_{i} R_{i}^{2}\right)-3(n+1)
$$

5. $\mathrm{R}: \mathrm{X}_{\mathrm{KW}}^{2}>\chi^{2}(1-\alpha ; \mathrm{r}-1)$

Multiple regression analysis was used for the purpose of constructing a model for prediction in this study. The dependent variable to be assigned in this study is the abundance of quahog larvae $(Y)$, and the independent variables are depths $\left(x_{1}\right)$, moon phase $\left(x_{2}\right)$ in respect to spring and neap tides, water temperature $\left(\mathrm{x}_{3}\right)$, and stations $\left(\mathrm{x}_{4}\right)$. A full model of multiple regression is :

$$
Y i=\beta_{0}+\beta_{1} x_{i 1}+\beta_{2} x_{i 2}+\beta_{3} x_{i 3}+\beta_{4} x_{i 4}+e_{i}
$$

where $\quad i=1,2, \ldots, n$

Stepwise regression analysis was also performed, using SAS software, to examine a better linear regression model. 


\section{RESULTS}

\section{Physical Environment}

Data of surface water temperature and salinity are presented in Table 1. Water temperature measured during the summer of 1995 ranged from 16.0 to $26.5^{\circ} \mathrm{C}$. During the early summer, the average water temperature was $19.7^{\circ} \mathrm{C}$. Temperature reached the highest point on July 28 (209th Julian day), $26.1^{\circ} \mathrm{C}$ in average. The temperature, then, gradually decreased.

Salinities were higher at Upper West Passage stations than those at stations of Upper Bay. The range was between 28 and 31 ppt at Upper West Passage stations; while at Upper Bay stations, salinity was between 26 and 29 ppt.

\section{Distribution of Larvae}

A total of 150 bivalve larval collections were taken from two depths $(0.3$ and $1.6 \mathrm{~m}$ ) at five sampling stations in Narragansett Bay during summer 1995, from May 26 (146th Julian day) to August 30 (242nd Julian day) (Table 2 and 3). The average percentage of quahog larvae relative to other bivalve larvae was 40 $\%$. Concentration ranges of total, early stage, and late stage quahog larvae were $0-19,740$ larvae, $0-19,680$, and $0-420$ larvae per $100 \mathrm{I}$, respectively. The quahog larvae in Upper Bay stations outnumbered those in stations of Upper West Passage. The early stage larvae were concentrated more in Rocky $\underline{P t}$, while the late ones were in Conimicut Pt., both stations located in Upper Bay. Other bivalve larvae ranged $0-15,840$ total larvae, $0-15,390$ early stage 
larvae, and $0-1,470$ late stage larvae per $100 \mathrm{l}$. Those larvae tended to concentrate also in Upper Bay stations.

Temporal distributions of Mercenaria mercenaria and other bivalve larvae, associated with daily water temperatures, are illustrated in Figures 2 to 11. The pattern of larval distributions in Wickford differed from those in other stations. The quahog larvae in Wickford were more concentrated in the early sampling days, as water temperatures were less warm. On the other hand, the larvae in other stations tended to invade water column as water temperatures got warmer.

On the first sampling day (May 26), temperature was about $16{ }^{\circ} \mathrm{C}$, early stage quahog larvae were only $4.9-45.8$ percent of the total early stage bivalve larvae. The densities were higher at Upper Bay stations, Conimicut Pt. $(1,965$ larvae per 100 I), Rocky Pt. (135 larvae per 100 I), and Warwick Pt. (555 larvae per $100 \mathrm{l}$ ), than those at Upper West Passage stations, Mt. View (150 larvae per $100 \mathrm{l})$ and Wickford (60 larvae per $100 \mathrm{l}$ ). The late stage of quahog larvae comprised only $0-15.9$ percent of the total late stage bivalve larvae. Numbers of quahog larvae at the late stage in Conimicut Pt., Warwick Pt., Mt. View, and Wickford were $45,20,15$, and 5 larvae per 100 I, respectively. No larva was present in the plankton samples taken from Rocky Pt.

Peak abundances of early stage larvae, age 1-3 days, occurred on June 20 (171st Julian day) at Conimicut Pt. (11,365 larvae per 100 I), Rocky Pt. (12,810 larvae per $100 \mathrm{l})$, Warwick Pt. $(6,155$ larvae per $100 \mathrm{l})$, and Mt. View $(3,595$ larvae per $100 \mathrm{I})$. The peak abundances coincided with increase water temperatures to above $20^{\circ} \mathrm{C}$. Quahog larvae predominated the population of bivalve larvae (as high as 72.5 percent). Early stage larval densities declined following the peak of June 20 ; average abundances were $639,675,287$, and 291 larvae per 100 l at Conimicut Pt., Rocky Pt., Warwick Pt., and Mt. View, 
respectively. The larvae at Wickford, however, showed different pattern. The maximum abundance (3,775 larvae per $100 \mathrm{I})$ occurred 11 days earlier (June 9) than that at other stations, where water temperature was only $19.5{ }^{\circ} \mathrm{C}$ when the peak occurred. Abundances, afterward, were less than 325 larvae per $100 \mathrm{I}$.

Maximum numbers of late stage veligers were observed on July 7 (188th Julian day) with abundances $165,60,230$, and 65 larvae per 100 I in respect to Conimicut Pt., Rocky Pt., Warwick Pt., and Mt. View. At Wickford, the peak of 40 larvae per 100 I on July 7 was not considered to be the maximum concentration since it was only at the factor of 1.5 lower than the peak on June 9 - 160th Julian day - (65 larvae per 100 I).

In respect to lunar phase, the peak abundances of quahog larvae generally occurred 6 to 12 days after new moon or full moon, and coincided with neap tides (Figure 12). During the intervening periods, the quahog larvae showed lower abundances. The evidence of major peak abundance of June 20 fell within a period of neap tide.

Mortality

As it is assumed that larval duration is about 2 to 3 weeks, the rate of survival of quahog larvae was estimated by calculating the ratio of late and early stage larvae with a time lag of $11-17$ days. The rate of mortality was obtained by subtracting the survival rate from 1 . Table 4 shows the rate of mortality of quahog larvae in Narragansett Bay which ranged from 80 to $99 \%$. Detailed calculation for mortality rate is presented on Appendix A. 


\section{Statistical Analyses}

This study evaluated four hypotheses. Linear correlation analysis was performed to detect an association between water temperature and abundances of quahog larvae. The correlation coefficients $(r)$ were relatively small, ranging between -0.28 and -0.04 (Figure $13-17$ ). These small numbers indicated that the relationship between water temperature and larval abundance is weak or there is almost no distinct relationship between these two variables, thus, the linear regression model does not seem to give a good fit to the data (Johnson and Bhattacharya, 1992).

A non parametric procedure utilized for comparing larval abundances in neap and spring tides demonstrated a significant difference (Table 5). This study, therefore, supports previous studies (Korringa, 1947; Carriker, 1961) which reported that the abundances of bivalve larvae were different during neap and spring tides. Another test proved that there was a significant difference among the abundances of quahog larvae in five sampling stations (Table 6). There is enough evidence to claim that the larval abundances were different among five sampling stations. However, this procedure failed to reject the nullhypothesis for testing the effects of depths on the larval abundances (Table 7). The present study failed to support the result of the Rice and Goncalo study (1994) that early stage larvae were found in higher number at upper water column ( 0.3 meter).

Coefficient of determination $\left(r^{2}\right)$ in multiple regression models determines how much variation of dependent variable can be accounted for by the model. Table 8 presents the result of multiple regression analysis between larval abundance and independent variables, i.e., water temperature, moon phase, stations, and depths. This full model, which included all variables, provided a very 
low $r^{2}(0.20)$. Thus, only $20 \%$ of the variation in the abundances of quahog larvae in Narragansett Bay can be explained by all of those independent variables.

A partial analysis of multiple regression (stepwise method) showed that the simpler model, which included only moon phase, had small $r^{2}$ of 0.09 (Table 9). By adding another independent variable (stations), $\mathrm{r}^{2}$ increased to 0.18 (Table 10). It appears that two other variables were not added into the model, because those, probably, gave less contribution to the increase of $r^{2}$. 
Table 1. Temperature (degree C) and salinity (ppt) at five sampling stations in Narragansett Bay during summer 1995. T, temperature; S, salinity; N/A, data not available; Numbers in parentheses denote Julian day.

\begin{tabular}{|c|c|c|c|c|c|c|c|c|c|c|}
\hline \multirow{2}{*}{ Date } & \multicolumn{2}{|c|}{ Conimicut $\mathrm{Pt}$. } & \multicolumn{2}{|c|}{ Rocky Pt. } & \multicolumn{2}{|c|}{ Warwick Pt. } & \multicolumn{2}{|c|}{ Mt. View } & \multicolumn{2}{|c|}{ Wickford } \\
\hline & $T$ & $\mathrm{~S}$ & $T$ & S & $T$ & S & $\mathrm{T}$ & $S$ & $T$ & $S$ \\
\hline \multirow{2}{*}{$\begin{array}{c}\text { 26-May } \\
(146)\end{array}$} & 16.50 & 26 & 16.50 & 27 & 16.50 & 27 & 16.50 & 29 & 16.00 & 31 \\
\hline & \multicolumn{2}{|c|}{$12: 00$} & \multicolumn{2}{|c|}{$12: 40$} & \multicolumn{2}{|c|}{ 13:28 } & \multicolumn{2}{|c|}{$14: 20$} & \multicolumn{2}{|c|}{$16: 20$} \\
\hline \multirow{2}{*}{$\begin{array}{c}\text { 31-May } \\
(151)\end{array}$} & 17.00 & 27 & 17.50 & 27 & 17.50 & 28 & 18.00 & 28 & N/A & N/A \\
\hline & \multicolumn{2}{|c|}{$11: 00$} & \multicolumn{2}{|c|}{$11: 52$} & \multicolumn{2}{|c|}{$12: 40$} & \multicolumn{2}{|c|}{$13: 25$} & & \\
\hline \multirow{2}{*}{$\begin{array}{l}\text { 9-Jun } \\
\text { (160) }\end{array}$} & 18.00 & 27 & 18.50 & 28 & 19.00 & 28 & 19.50 & 29 & 19.50 & 30 \\
\hline & \multicolumn{2}{|c|}{$9: 05$} & \multicolumn{2}{|c|}{$10: 06$} & \multicolumn{2}{|c|}{$10: 36$} & \multicolumn{2}{|c|}{$11: 21$} & \multicolumn{2}{|c|}{$12: 01$} \\
\hline \multirow{2}{*}{$\begin{array}{c}\text { 14-Jun } \\
\text { (165) }\end{array}$} & 17.00 & 26 & 17.00 & 26 & 16.50 & 28 & 17.00 & 30 & 17.00 & 31 \\
\hline & \multicolumn{2}{|c|}{$10: 32$} & \multicolumn{2}{|c|}{$11: 21$} & \multicolumn{2}{|c|}{$12: 08$} & \multicolumn{2}{|c|}{$13: 05$} & \multicolumn{2}{|c|}{$3: 10$} \\
\hline \multirow{2}{*}{$\begin{array}{c}\text { 20-Jun } \\
(171)\end{array}$} & 23.00 & 27 & 22.00 & 27 & 23.00 & 27 & 22.00 & 29 & 22.00 & 31 \\
\hline & \multicolumn{2}{|c|}{$10: 45$} & \multicolumn{2}{|c|}{$11: 45$} & \multicolumn{2}{|c|}{$12: 20$} & \multicolumn{2}{|c|}{$13: 15$} & \multicolumn{2}{|c|}{$14: 52$} \\
\hline 28-Jun & 20.00 & 27 & 20.00 & 28 & 20.50 & 28 & 21.50 & 29 & 22.00 & 30 \\
\hline$(179)$ & & & & & & & & & & \\
\hline 7-Jul & 22.50 & 28 & 22.50 & 28 & 23.00 & 29 & 22.00 & 30 & 21.50 & 31 \\
\hline (188) & & & & & & & & & & \\
\hline 13-Jul & 21.50 & 27 & 22.00 & 27 & 22.00 & 28 & 22.50 & 29 & 22.00 & 29 \\
\hline$(194)$ & & & & & & & & & & \\
\hline
\end{tabular}


Table 1. Continued

\begin{tabular}{|c|c|c|c|c|c|c|c|c|c|c|}
\hline \multirow[t]{2}{*}{ Date } & \multicolumn{2}{|c|}{ Conimicut Pt. } & \multicolumn{2}{|c|}{ Rocky Pt. } & \multicolumn{2}{|c|}{ Warwick Pt. } & \multicolumn{2}{|c|}{ Mt. View } & \multicolumn{2}{|c|}{ Wickford } \\
\hline & $T$ & $\mathrm{~S}$ & $T$ & $S$ & $T$ & $\mathrm{~S}$ & $T$ & $\mathrm{~S}$ & $T$ & $S$ \\
\hline 19-Jul & 22.50 & 28 & 22.50 & 28 & 23.00 & 29 & 23.50 & 30 & 22.50 & 30 \\
\hline$(200)$ & \multicolumn{2}{|c|}{$11: 20$} & \multicolumn{2}{|c|}{$12: 00$} & \multicolumn{2}{|c|}{$12: 50$} & \multicolumn{2}{|c|}{$13: 35$} & \multicolumn{2}{|c|}{$14: 25$} \\
\hline 28-Jul & 26.50 & 27 & 26.50 & 27 & 26.50 & 27 & 26.00 & 29 & 25.00 & 31 \\
\hline (209) & \multicolumn{2}{|c|}{$10: 45$} & \multicolumn{2}{|c|}{$11: 20$} & \multicolumn{2}{|c|}{$11: 50$} & \multicolumn{2}{|c|}{$12: 30$} & \multicolumn{2}{|c|}{$14: 30$} \\
\hline 4-Aug & 25.00 & 26 & 25.00 & 27 & 25.00 & 28 & 25.00 & 29 & 25.00 & 29 \\
\hline$(216)$ & \multicolumn{2}{|c|}{$9: 40$} & \multicolumn{2}{|c|}{$10: 15$} & \multicolumn{2}{|c|}{$10: 40$} & \multicolumn{2}{|c|}{$11: 20$} & \multicolumn{2}{|c|}{$12: 05$} \\
\hline 9-Aug & 22.50 & 27 & 22.50 & 28 & 22.50 & 29 & 23.50 & 30 & 23.50 & 31 \\
\hline$(221)$ & \multicolumn{2}{|c|}{$11: 00$} & \multicolumn{2}{|c|}{$11: 30$} & \multicolumn{2}{|c|}{$12: 00$} & \multicolumn{2}{|c|}{$12: 35$} & \multicolumn{2}{|c|}{$13: 30$} \\
\hline 14-Aug & 24.00 & 27 & 24.00 & 28 & 24.00 & 28 & 23.50 & 30 & 24.00 & 30 \\
\hline$(226)$ & \multicolumn{2}{|c|}{$10: 37$} & \multicolumn{2}{|c|}{$11: 10$} & \multicolumn{2}{|c|}{$11: 35$} & \multicolumn{2}{|c|}{$12: 10$} & \multicolumn{2}{|c|}{$12: 55$} \\
\hline 23-Aug & 22.00 & 28 & 22.00 & 28 & 22.50 & 28 & 23.00 & 29 & 23.00 & 31 \\
\hline$(235)$ & \multicolumn{2}{|c|}{$10: 35$} & \multicolumn{2}{|c|}{$11: 15$} & \multicolumn{2}{|c|}{$11: 45$} & \multicolumn{2}{|c|}{$12: 30$} & \multicolumn{2}{|c|}{ 13:00 } \\
\hline 30-Aug & 21.00 & 27 & 21.00 & 27 & 21.50 & 28 & 22.00 & 29 & 21.50 & 31 \\
\hline (242) & & & & & & & & & & \\
\hline
\end{tabular}


Table 2. Densities of quahog larvae (per $100 \mathrm{l}$ ) at two sampling depths in five stations of Narragansett Bay during summer 1995. T, total larvae; E, early stage larvae (see text); L, late stage larvae (see text); N/A, data not available; Numbers in parentheses denote Julian day.

\begin{tabular}{|c|c|c|c|c|c|c|c|c|c|c|c|c|c|c|c|c|}
\hline \multirow[t]{2}{*}{ Date } & \multirow{2}{*}{$\begin{array}{l}\text { Depth } \\
\text { (m) }\end{array}$} & \multicolumn{3}{|c|}{ Conimicut Pt. } & \multicolumn{3}{|c|}{ Rocky Pt. } & \multicolumn{3}{|c|}{ Warwick Pt. } & \multicolumn{3}{|c|}{ Mt. View } & \multicolumn{3}{|c|}{ Wickford } \\
\hline & & $\mathrm{T}$ & $E$ & $L$ & $\mathrm{~T}$ & $E$ & $L$ & $\mathrm{~T}$ & $E$ & $L$ & $\mathrm{~T}$ & $E$ & $L$ & $\mathrm{~T}$ & $E$ & $L$ \\
\hline \multirow{3}{*}{$\begin{array}{c}\text { 26-May } \\
\text { (146) }\end{array}$} & 0.30 & 1830 & 1810 & 20 & 20 & 20 & 0 & 340 & 330 & 10 & 60 & 60 & 0 & 40 & 40 & 0 \\
\hline & 1.60 & 2190 & 2120 & 70 & 250 & 250 & 0 & 810 & 780 & 30 & 270 & 240 & 30 & 90 & 80 & 10 \\
\hline & & & $12: 00$ & & & $12: 40$ & & & $13: 28$ & & & $14: 20$ & & & $16: 20$ & \\
\hline \multirow{3}{*}{$\begin{array}{c}\text { 31-May } \\
\text { (151) }\end{array}$} & 0.30 & 60 & 60 & 0 & 40 & 40 & 0 & 70 & 70 & 0 & 130 & 130 & 0 & N/A & N/A & $N / A$ \\
\hline & 1.60 & 760 & 720 & 40 & 60 & 60 & 0 & 190 & 150 & 40 & 210 & 200 & 10 & $\mathrm{~N} / \mathrm{A}$ & $\mathrm{N} / \mathrm{A}$ & N/A \\
\hline & & & $11: 00$ & & & $11: 52$ & & & $12: 40$ & & & $13: 25$ & & & & \\
\hline \multirow{3}{*}{$\begin{array}{l}\text { 9-Jun } \\
\text { (160) }\end{array}$} & 0.30 & 2870 & 2850 & 20 & 4410 & 4410 & 0 & 1340 & 1310 & 30 & 340 & 340 & 0 & 690 & 690 & 0 \\
\hline & 1.60 & 990 & 980 & 10 & 3580 & 3580 & 0 & 1950 & 1920 & 30 & 1780 & 1710 & 70 & 6990 & 6860 & 130 \\
\hline & & & 9:05 & & & $10: 06$ & & & $10: 36$ & & & $11: 21$ & & & $12: 01$ & \\
\hline \multirow{3}{*}{$\begin{array}{c}\text { 14-Jun } \\
(165)\end{array}$} & 0.30 & 100 & 100 & 0 & 60 & 40 & 20 & 90 & 90 & 0 & 60 & 40 & 20 & 240 & 200 & 40 \\
\hline & 1.60 & 210 & 190 & 20 & 200 & 200 & 0 & 120 & 120 & 0 & 90 & 80 & 10 & 90 & 90 & 0 \\
\hline & & & $10: 32$ & & & $11: 21$ & & & $12: 08$ & & & 13:05 & & & $3: 10$ & \\
\hline \multirow{3}{*}{$\begin{array}{c}\text { 20-Jun } \\
(171)\end{array}$} & 0.30 & 7760 & 7760 & 0 & 5950 & 5940 & 10 & 6820 & 6820 & 0 & 5710 & 5700 & 10 & 80 & 80 & 0 \\
\hline & 1.60 & 14970 & 14970 & 0 & 19740 & 19680 & 60 & 5500 & 5490 & 10 & 1500 & 1490 & 10 & 80 & 80 & 0 \\
\hline & & & $10: 45$ & & & $11: 45$ & & & $12: 20$ & & & 13:15 & & & $14: 52$ & \\
\hline \multirow{3}{*}{$\begin{array}{c}\text { 28-Jun } \\
\text { (179) }\end{array}$} & 0.30 & 230 & 230 & 0 & 290 & 290 & 0 & 550 & 540 & 10 & 340 & 340 & 0 & 210 & 210 & 0 \\
\hline & 1.60 & 1060 & 970 & 90 & 850 & 840 & 10 & 1930 & 1870 & 60 & 710 & 680 & 30 & 220 & 220 & 0 \\
\hline & & & $10: 30$ & & & $11: 10$ & & & $11: 55$ & & & $12: 30$ & & & $13: 30$ & \\
\hline
\end{tabular}


Table 2. Continued.

\begin{tabular}{|c|c|c|c|c|c|c|c|c|c|c|c|c|c|c|c|c|}
\hline \multirow[t]{2}{*}{ Date } & \multirow{2}{*}{$\begin{array}{l}\text { Depth } \\
\text { (m) }\end{array}$} & \multicolumn{3}{|c|}{ Conimicut Pt. } & \multicolumn{3}{|c|}{ Rocky Pt. } & \multicolumn{3}{|c|}{ Warwick Pt. } & \multicolumn{3}{|c|}{ Mt. View } & \multicolumn{3}{|c|}{ Wickford } \\
\hline & & $T$ & $E$ & $L$ & $T$ & $E$ & $\mathrm{~L}$ & $T$ & $E$ & $L$ & $T$ & $E$ & $L$ & $T$ & $E$ & $L$ \\
\hline 7-Jul & 0.30 & 20 & 20 & 0 & 1660 & 1580 & 80 & 450 & 410 & 40 & 990 & 920 & 70 & 680 & 620 & 60 \\
\hline \multirow[t]{2}{*}{ (188) } & 1.60 & 3270 & 2940 & 330 & 1800 & 1760 & 40 & 480 & 60 & 420 & 1350 & 1290 & 60 & 50 & 30 & 20 \\
\hline & & & $10: 30$ & & & $11: 20$ & & & $12: 08$ & & & $12: 50$ & & & $14: 45$ & \\
\hline \multirow{3}{*}{$\begin{array}{c}\text { 13-Jul } \\
\text { (194) }\end{array}$} & 0.30 & 30 & 20 & 10 & 160 & 150 & 10 & 40 & 30 & 10 & 80 & 70 & 10 & 90 & 90 & 0 \\
\hline & 1.60 & 720 & 670 & 50 & 40 & 30 & 10 & 20 & 20 & 0 & 60 & 40 & 20 & 10 & 10 & 0 \\
\hline & & & $10: 30$ & & & $11: 15$ & & & $11: 55$ & & & $12: 30$ & & & $14: 35$ & \\
\hline \multirow{3}{*}{$\begin{array}{l}\text { 19-Jul } \\
(200)\end{array}$} & 0.30 & 300 & 180 & 120 & 1750 & 1700 & 50 & 40 & 40 & 0 & 240 & 230 & 10 & 70 & 70 & 0 \\
\hline & 1.60 & 1410 & 1280 & 130 & 50 & 30 & 20 & 584 & 560 & 24 & 310 & 270 & 40 & 110 & 100 & 10 \\
\hline & & & $11: 20$ & & & $12: 00$ & & & $12: 50$ & & & $13: 35$ & & & $14: 25$ & \\
\hline \multirow{3}{*}{$\begin{array}{l}\text { 28-Jul } \\
\text { (209) }\end{array}$} & 0.30 & 920 & 920 & 0 & 1060 & 1020 & 40 & 60 & 60 & 0 & 10 & 10 & 0 & 170 & 170 & 0 \\
\hline & 1.60 & 20 & 0 & 20 & 70 & 60 & 10 & 400 & 400 & 0 & 540 & 540 & 0 & 0 & 0 & 0 \\
\hline & & & $10: 45$ & & & $11: 20$ & & & $11: 50$ & & & $12: 30$ & & & $14: 30$ & \\
\hline \multirow{3}{*}{$\begin{array}{c}\text { 4-Aug } \\
(216)\end{array}$} & 0.30 & 20 & 20 & 0 & 4800 & 4800 & 0 & 1070 & 1070 & 0 & 60 & 50 & 10 & 80 & 80 & 0 \\
\hline & 1.60 & 4260 & 4240 & 20 & 60 & 50 & 10 & 30 & 30 & 0 & 980 & 980 & 0 & 440 & 420 & 20 \\
\hline & & & $9: 40$ & & & $10: 15$ & & & $10: 40$ & & & $11: 20$ & & & $12: 05$ & \\
\hline \multirow{3}{*}{$\begin{array}{l}\text { 9-Aug } \\
\text { (221) }\end{array}$} & 0.30 & 0 & 0 & 0 & 0 & 0 & 0 & 90 & 90 & 0 & 40 & 40 & 0 & 40 & 40 & 0 \\
\hline & 1.60 & 100 & 100 & 0 & 100 & 90 & 10 & 30 & 30 & 0 & 60 & 30 & 30 & 20 & 20 & 0 \\
\hline & & & $11: 00$ & & & $11: 30$ & & & $12: 00$ & & & $12: 35$ & & & $13: 30$ & \\
\hline
\end{tabular}


Table 2. Continued.

\begin{tabular}{|c|c|c|c|c|c|c|c|c|c|c|c|c|c|c|c|c|}
\hline \multirow{2}{*}{ Date } & \multirow{2}{*}{$\begin{array}{c}\text { Depth } \\
\text { (m) }\end{array}$} & \multicolumn{3}{|c|}{ Conimicut Pt. } & \multicolumn{3}{|c|}{ Rocky Pt. } & \multicolumn{3}{|c|}{ Warwick Pt. } & \multicolumn{3}{|c|}{ Mt. View } & \multicolumn{3}{|c|}{ Wickford } \\
\hline & & $\mathrm{T}$ & $E$ & $\mathrm{~L}$ & $\mathrm{~T}$ & $E$ & $\mathrm{~L}$ & $\mathrm{~T}$ & $E$ & L & $\mathrm{T}$ & $E$ & $L$ & $T$ & $E$ & $L$ \\
\hline 14-Aug & 0.30 & 40 & 40 & 0 & 30 & 20 & 10 & 50 & 50 & 0 & 20 & 20 & 0 & 20 & 20 & 0 \\
\hline \multirow[t]{2}{*}{$(226)$} & 1.60 & 80 & 60 & 20 & 80 & 60 & 20 & 0 & 0 & 0 & 40 & 30 & 10 & 50 & 50 & 0 \\
\hline & & & $10: 37$ & & & $11: 10$ & & & $11: 35$ & & & $12: 10$ & & & $12: 55$ & \\
\hline \multirow{3}{*}{$\begin{array}{c}\text { 23-Aug } \\
(235)\end{array}$} & 0.30 & 0 & 0 & 0 & 0 & 0 & 0 & 90 & 90 & 0 & 30 & 30 & 0 & 0 & 0 & 0 \\
\hline & 1.60 & 960 & 930 & 30 & 770 & 750 & 20 & 70 & 40 & 30 & 30 & 20 & 10 & 30 & 30 & 0 \\
\hline & & & $10: 35$ & & & $11: 15$ & & & $11: 45$ & & & $12: 30$ & & & $13: 00$ & \\
\hline \multirow{3}{*}{$\begin{array}{c}\text { 30-Aug } \\
(242)\end{array}$} & 0.30 & 10 & 10 & 0 & 120 & 120 & 0 & 10 & 10 & 0 & 210 & 210 & 0 & 0 & 0 & 0 \\
\hline & 1.60 & 150 & 150 & 0 & 150 & 140 & 10 & 330 & 330 & 0 & 20 & 20 & 0 & 120 & 120 & 0 \\
\hline & & & $10: 55$ & & & $11: 30$ & & & $12: 00$ & & & $12: 35$ & & & $13: 20$ & \\
\hline Average & & 1511 & 1478 & 33 & 1605 & 1590 & 15 & 785 & 760 & 25 & 542 & 527 & 15 & 383 & 372 & 10 \\
\hline
\end{tabular}


Table 3. Densities of other bivalve larvae (per $100 \mathrm{I}$ ) at two sampling depths in five stations of Narragansett Bay during summer 1995. $T$, total larvae; $E$, early stage larvae (see text); $L$, late stage larvae (see text); N/A, data not available; Numbers in parentheses denote Julian day.

\begin{tabular}{|c|c|c|c|c|c|c|c|c|c|c|c|c|c|c|c|c|}
\hline \multirow[t]{2}{*}{ Date } & \multirow{2}{*}{$\begin{array}{l}\text { Depth } \\
\text { (m) }\end{array}$} & \multicolumn{3}{|c|}{ Conimicut Pt. } & \multicolumn{3}{|c|}{ Rocky Pt. } & \multicolumn{3}{|c|}{ Warwick Pt. } & \multicolumn{3}{|c|}{ Mt. View } & \multicolumn{3}{|c|}{ Wickford } \\
\hline & & $T$ & $E$ & $L$ & $T$ & $E$ & $L$ & $T$ & $E$ & $\underline{L}$ & $T$ & $\mathrm{E}$ & L & $\mathrm{T}$ & $E$ & $\mathrm{~L}$ \\
\hline \multirow{3}{*}{$\begin{array}{c}\text { 26-May } \\
(146)\end{array}$} & 0.30 & 9450 & 9420 & 30 & 30 & 30 & 0 & 3180 & 3120 & 60 & 1710 & 1620 & 90 & 1160 & 1120 & 40 \\
\hline & 1.60 & 15840 & 15390 & 450 & 300 & 290 & 10 & 5440 & 5140 & 300 & 1760 & 1650 & 110 & 1240 & 1200 & 40 \\
\hline & & & $12: 00$ & & & $12: 40$ & & & $13: 28$ & & & $14: 20$ & & & $16: 20$ & \\
\hline \multirow{3}{*}{$\begin{array}{c}\text { 31-May } \\
\text { (151) }\end{array}$} & 0.30 & 80 & 60 & 20 & 100 & 100 & 0 & 110 & 110 & 0 & 230 & 190 & 40 & $N / A$ & $\mathrm{~N} / \mathrm{A}$ & N/A \\
\hline & 1.60 & 3730 & 3540 & 190 & 200 & 170 & 30 & 410 & 320 & 90 & 660 & 600 & 60 & $N / A$ & $\mathrm{~N} / \mathrm{A}$ & $N / A$ \\
\hline & & & $11: 00$ & & & $11: 52$ & & & $12: 40$ & & & $13: 25$ & & & & \\
\hline \multirow{3}{*}{$\begin{array}{l}\text { 9-Jun } \\
\text { (160) }\end{array}$} & 0.30 & 1920 & 1890 & 30 & 1950 & 1950 & 0 & 750 & 720 & 30 & 420 & 390 & 30 & 240 & 240 & 0 \\
\hline & 1.60 & 660 & 660 & 0 & 1890 & 1830 & 60 & 990 & 990 & 0 & 1440 & 1350 & 90 & 2310 & 2250 & 60 \\
\hline & & & 9:05 & & & $10: 06$ & & & $10: 36$ & & & $11: 21$ & & & $12: 01$ & \\
\hline \multirow{3}{*}{$\begin{array}{c}\text { 14-Jun } \\
\text { (165) }\end{array}$} & 0.30 & 330 & 240 & 90 & 480 & 390 & 90 & 420 & 420 & 0 & 240 & 210 & 30 & 1620 & 1560 & 60 \\
\hline & 1.60 & 810 & 600 & 210 & 990 & 870 & 120 & 600 & 510 & 90 & 540 & 450 & 90 & 690 & 570 & 120 \\
\hline & & & $10: 32$ & & & $11: 21$ & & & $12: 08$ & & & 13:05 & & & $3: 10$ & \\
\hline \multirow{3}{*}{$\begin{array}{c}\text { 20-Jun } \\
(171)\end{array}$} & 0.30 & 1810 & 1780 & 30 & 2400 & 2400 & 0 & 4640 & 4590 & 50 & 5630 & 5520 & 110 & 2190 & 2150 & 40 \\
\hline & 1.60 & 7170 & 7170 & 0 & 7380 & 7340 & 40 & 2820 & 2790 & 30 & 1390 & 1390 & 0 & 1820 & 1770 & 50 \\
\hline & & & $10: 45$ & & & $11: 45$ & & & $12: 20$ & & & $13: 15$ & & & $14: 52$ & \\
\hline \multirow{3}{*}{$\begin{array}{l}\text { 28-Jun } \\
\text { (179) }\end{array}$} & 0.30 & 390 & 330 & 60 & 200 & 200 & 0 & 350 & 350 & 0 & 140 & 110 & 30 & 340 & 340 & 0 \\
\hline & 1.60 & 2250 & 1770 & 480 & 580 & 480 & 100 & 1610 & 1370 & 240 & 610 & 430 & 180 & 390 & 390 & 0 \\
\hline & & & $10: 30$ & & & $11: 10$ & & & $11: 55$ & & & $12: 30$ & & & $13: 30$ & \\
\hline
\end{tabular}


Table 3. Continued.

\begin{tabular}{|c|c|c|c|c|c|c|c|c|c|c|c|c|c|c|c|c|}
\hline \multirow[t]{2}{*}{ Date } & \multirow{2}{*}{$\begin{array}{l}\text { Depth } \\
\text { (m) }\end{array}$} & \multicolumn{3}{|c|}{ Conimicut Pt. } & \multicolumn{3}{|c|}{ Rocky Pt. } & \multicolumn{3}{|c|}{ Warwick Pt. } & \multicolumn{3}{|c|}{ Mt. View } & \multicolumn{3}{|c|}{ Wiakford } \\
\hline & & $T$ & $E$ & $L$ & $T$ & $\mathrm{E}$ & $\mathrm{L}$ & $T$ & $\mathrm{E}$ & $\underline{L}$ & $T$ & $E$ & L & $T$ & $E$ & $\mathrm{~L}$ \\
\hline 7-Jul & 0.30 & 1020 & 930 & 90 & 3430 & 2810 & 620 & 670 & 520 & 150 & 2770 & 2020 & 750 & 3600 & 3040 & 560 \\
\hline \multirow[t]{2}{*}{ (188) } & 1.60 & 5930 & 4510 & 1420 & 4960 & 4560 & 400 & 3980 & 3600 & 380 & 3080 & 2520 & 560 & 650 & 580 & 70 \\
\hline & & & $10: 30$ & & & $11: 20$ & & & $12: 08$ & & & $12: 50$ & & & $14: 45$ & \\
\hline \multirow{3}{*}{$\begin{array}{l}\text { 13-Jul } \\
\text { (194) }\end{array}$} & 0.30 & 330 & 310 & 20 & 520 & 430 & 90 & 400 & 370 & 30 & 510 & 460 & 50 & 160 & 150 & 10 \\
\hline & 1.60 & 190 & 180 & 10 & 260 & 220 & 40 & 150 & 120 & 30 & 160 & 130 & 30 & 400 & 340 & 60 \\
\hline & & & $10: 30$ & & & $11: 15$ & & & $11: 55$ & & & $12: 30$ & & & $14: 35$ & \\
\hline \multirow{3}{*}{$\begin{array}{l}\text { 19-Jul } \\
(200)\end{array}$} & 0.30 & 3620 & 3400 & 220 & 3780 & 3210 & 570 & 250 & 250 & 0 & 1200 & 920 & 280 & 1820 & 1730 & 90 \\
\hline & 1.60 & 2500 & 2160 & 340 & 710 & 570 & 140 & 1630 & 1580 & 50 & 1580 & 1500 & 80 & 3880 & 3770 & 110 \\
\hline & & & $11: 20$ & & & $12: 00$ & & & $12: 50$ & & & 13:35 & & & $14: 25$ & \\
\hline \multirow{3}{*}{$\begin{array}{l}\text { 28-Jul } \\
\text { (209) }\end{array}$} & 0.30 & 1360 & 1330 & 30 & 2490 & 2140 & 350 & 180 & 150 & 30 & 350 & 300 & 50 & 660 & 610 & 50 \\
\hline & 1.60 & 810 & 780 & 30 & 630 & 570 & 60 & 740 & 660 & 80 & 860 & 780 & 80 & 70 & 60 & 10 \\
\hline & & & $10: 45$ & & & $11: 20$ & & & $11: 50$ & & & $12: 30$ & & & $14: 30$ & \\
\hline \multirow{3}{*}{$\begin{array}{c}\text { 4-Aug } \\
(216)\end{array}$} & 0.30 & 1430 & 1160 & 270 & 3450 & 3240 & 210 & 1840 & 1770 & 70 & 1920 & 1490 & 430 & 420 & 360 & 60 \\
\hline & 1.60 & 770 & 690 & 80 & 760 & 610 & 150 & 470 & 320 & 150 & 1390 & 1300 & 90 & 840 & 800 & 40 \\
\hline & & & $9: 40$ & & & $10: 15$ & & & $10: 40$ & & & $11: 20$ & & & $12: 05$ & \\
\hline \multirow{3}{*}{$\begin{array}{l}\text { 9-Aug } \\
\text { (221) }\end{array}$} & 0.30 & 110 & 60 & 50 & 30 & 20 & 10 & 150 & 130 & 20 & 0 & 0 & 0 & 180 & 130 & 50 \\
\hline & 1.60 & 150 & 120 & 30 & 130 & 90 & 40 & 90 & 60 & 30 & 260 & 220 & 40 & 70 & 50 & 20 \\
\hline & & & $11: 00$ & & & $11: 30$ & & & $12: 00$ & & & $12: 35$ & & & $13: 30$ & \\
\hline
\end{tabular}


Table 3. Continued.

\begin{tabular}{|c|c|c|c|c|c|c|c|c|c|c|c|c|c|c|c|c|}
\hline \multirow[t]{2}{*}{ Date } & \multirow{2}{*}{$\begin{array}{c}\text { Depth } \\
\text { (m) }\end{array}$} & \multicolumn{3}{|c|}{ Conimicut Pt. } & \multicolumn{3}{|c|}{ Rocky Pt. } & \multicolumn{3}{|c|}{ Warwick Pt. } & \multicolumn{3}{|c|}{ Mt. View } & \multicolumn{3}{|c|}{ Wickford } \\
\hline & & $T$ & $E$ & $L$ & $T$ & $E$ & $L$ & $T$ & $E$ & $L$ & $T$ & $E$ & $L$ & $T$ & $E$ & $L$ \\
\hline 14-Aug & 0.30 & 1780 & 1540 & 240 & 3470 & 3150 & 320 & 1180 & 1070 & 110 & 20 & 20 & 0 & 260 & 240 & 20 \\
\hline \multirow[t]{2}{*}{$(226)$} & 1.60 & 70 & 40 & 30 & 200 & 150 & 50 & 150 & 130 & 20 & 1780 & 1710 & 70 & 1070 & 1050 & 20 \\
\hline & & & $10: 37$ & & & $11: 10$ & & & $11: 35$ & & & $12: 10$ & & & $12: 55$ & \\
\hline \multirow{3}{*}{$\begin{array}{c}\text { 23-Aug } \\
(235)\end{array}$} & 0.30 & 150 & 120 & 30 & 70 & 50 & 20 & 620 & 600 & 20 & 3540 & 2070 & 1470 & 20 & 20 & 0 \\
\hline & 1.60 & 3180 & 3000 & 180 & 3030 & 2280 & 750 & 0 & 0 & 0 & 30 & 30 & 0 & 1020 & 870 & 150 \\
\hline & & & $10: 35$ & & & $11: 15$ & & & $11: 45$ & & & $12: 30$ & & & 13:00 & \\
\hline \multirow{3}{*}{$\begin{array}{c}\text { 30-Aug } \\
(242)\end{array}$} & 0.30 & 40 & 30 & 10 & 240 & 150 & 90 & 0 & 0 & 0 & 540 & 540 & 0 & 30 & 30 & 0 \\
\hline & 1.60 & 1080 & 960 & 120 & 450 & 410 & 40 & 1080 & 900 & 180 & 20 & 20 & 0 & 630 & 630 & 0 \\
\hline & & & $10: 55$ & & & $11: 30$ & & & $12: 00$ & & & $12: 35$ & & & $13: 20$ & \\
\hline Average & & 2299 & 2139 & 160 & 1504 & 1357 & 147 & 1163 & 1089 & 75 & 1152 & 998 & 161 & 992.1 & 930.4 & 62 \\
\hline
\end{tabular}


Table 4. Rate of mortality of quahog larvae in Narragansett Bay during summer 1995. Cohort is defined as a group of larvae at an early stage developing into the late stage within $11-17$ days.

\begin{tabular}{cr}
\hline cohort & Mortality \\
\hline 1 & $94.90 \%$ \\
2 & $93.80 \%$ \\
3 & $99.60 \%$ \\
4 & $82.60 \%$ \\
5 & $98.35 \%$ \\
6 & $98.06 \%$ \\
7 & $95.80 \%$ \\
8 & $93.81 \%$ \\
9 & $98.65 \%$ \\
10 & $98.74 \%$ \\
11 & $99.49 \%$ \\
12 & $79.55 \%$ \\
13 & $97.14 \%$ \\
\hline
\end{tabular}


Table 5. Non-parametric procedure to determine whether there is a difference between abundances of quahog larvae during neap (N.T) and spring (S.T) tides in Narragansett Bay in the summer of 1995.

\begin{tabular}{cccc}
\hline N.T & RANK & S.T & RANK \\
\hline 0 & 4.5 & 0 & 4.5 \\
0 & 4.5 & 0 & 4.5 \\
10 & 10.5 & 0 & 4.5 \\
10 & 10.5 & 0 & 4.5 \\
20 & 17 & 0 & 4.5 \\
20 & 17 & 0 & 4.5 \\
20 & 17 & 10 & 10.5 \\
20 & 17 & 10 & 10.5 \\
20 & 17 & 20 & 17 \\
20 & 17 & 20 & 17 \\
30 & 25 & 20 & 17 \\
30 & 25 & 30 & 25 \\
40 & 33 & 30 & 25 \\
40 & 33 & 30 & 25 \\
40 & 33 & 30 & 25 \\
40 & 33 & 30 & 25 \\
50 & 39.5 & 40 & 33 \\
50 & 39.5 & 40 & 33 \\
50 & 39.5 & 40 & 33 \\
50 & 39.5 & 40 & 33 \\
60 & 46.5 & 40 & 33 \\
60 & 46.5 & 60 & 46.5 \\
60 & 46.5 & 60 & 46.5 \\
70 & 53.5 & 60 & 46.5 \\
80 & 58.5 & 60 & 46.5 \\
80 & 58.5 & 60 & 46.5 \\
80 & 58.5 & 60 & 46.5 \\
80 & 58.5 & 60 & 46.5 \\
80 & 58.5 & 70 & 53.5 \\
90 & 65 & 70 & 53.5 \\
110 & 72 & 70 & 53.5 \\
120 & 74 & 80 & 58.5 \\
120 & 74 & 90 & 65 \\
150 & 77.5 & 90 & 65 \\
150 & 77.5 & 90 & 65 \\
210 & 84.5 & 90 & 65 \\
240 & 89.5 & 90 & 65 \\
250 & 91 & 90 & 65 \\
270 & 92 & 100 & 70 \\
\hline & & &
\end{tabular}


Table 5. Continued

\begin{tabular}{cccc}
\hline N.T & RANK & S.T & RANK \\
\hline 300 & 94 & 100 & 70 \\
310 & 95 & 100 & 70 \\
330 & 96 & 120 & 74 \\
340 & 98 & 130 & 76 \\
340 & 98 & 160 & 79 \\
440 & 101 & 170 & 80 \\
450 & 102 & 190 & 81 \\
480 & 103 & 200 & 82 \\
584 & 106 & 210 & 84.5 \\
680 & 107 & 210 & 84.5 \\
810 & 112 & 210 & 84.5 \\
980 & 116 & 220 & 87 \\
990 & 118 & 230 & 88 \\
990 & 118 & 240 & 89.5 \\
1070 & 121 & 290 & 93 \\
1340 & 122 & 340 & 98 \\
1350 & 123 & 400 & 100 \\
1410 & 124 & 540 & 104 \\
1660 & 125 & 550 & 105 \\
1750 & 126 & 710 & 108 \\
1780 & 127 & 720 & 109 \\
1800 & 128 & 760 & 110 \\
1830 & 129 & 770 & 111 \\
1950 & 131 & 850 & 113 \\
2190 & 132 & 920 & 114 \\
2870 & 133 & 960 & 115 \\
3270 & 134 & 1060 & 120 \\
3580 & 135 & 1060 & 120 \\
4260 & 136 & 1930 & 130 \\
4410 & 137 & & \\
4800 & 138 & & \\
\hline & & &
\end{tabular}

$W_{A}=4172.5$

Mean rank $=4726 ;$ Standard deviation $=234.8$

$Z=\left(W_{A}-\right.$ Mean rank $) /$ Standard deviation $=-2.36 ; Z_{\alpha / 2}=-1.96$

$R:|Z| \geq-1.96$

Since $Z=-2.36$ falls in the rejection region, then $H_{0}$ is rejected 
Table 6. Non-parametric test, using Kruskal-Wallis method, to determine whether there are differences of quahog larval abundances among five stations.

\begin{tabular}{|c|c|c|c|c|c|c|c|c|c|c|}
\hline \multirow[t]{2}{*}{ Date } & \multicolumn{2}{|c|}{ Conimicut Pt. } & \multicolumn{2}{|c|}{ Rocky Pt. } & \multicolumn{2}{|c|}{ Warwick Pt. } & \multicolumn{2}{|c|}{ Mt. View } & \multicolumn{2}{|c|}{ Wickford } \\
\hline & Larvae & Rank & Larvae & Rank & Larvae & Rank & Larvae & Rank & Larvae & Rank \\
\hline 26-May & 2010 & 49 & 135 & 18 & 575 & 39 & 165 & 20 & 65 & 8 \\
\hline 31-May & 410 & 30 & 50 & 5 & 130 & 17 & 170 & 21 & N/A & N/A \\
\hline 9-Jun & 1930 & 48 & 3995 & 54 & 1645 & 46 & 1060 & 43 & 3840 & 53 \\
\hline 14-Jun & 155 & 19 & 130 & 17 & 105 & 15 & 75 & 10 & 165 & 20 \\
\hline 20-Jun & 11365 & 56 & 12845 & 57 & 6160 & 55 & 3605 & 52 & 80 & 11 \\
\hline 28-Jun & 645 & 40 & 570 & 38 & 1240 & 45 & 525 & 35 & 215 & 22 \\
\hline 7-Jul & 1645 & 46 & 1730 & 47 & 465 & 31 & 1170 & 44 & 365 & 27 \\
\hline 13-Jul & 375 & 28 & 100 & 14 & 30 & 3 & 70 & 9 & 50 & 5 \\
\hline 19-Jul & 855 & 41 & 900 & 42 & 312 & 26 & 275 & 25 & 90 & 13 \\
\hline 28-Jul & 470 & 32 & 565 & 37 & 230 & 23 & 275 & 25 & 85 & 12 \\
\hline 4-Aug & 2140 & 50 & 2430 & 51 & 550 & 36 & 520 & 34 & 260 & 24 \\
\hline 9-Aug & 50 & 5 & 50 & 5 & 60 & 7 & 50 & 5 & 30 & 3 \\
\hline 14-Aug & 60 & 7 & 55 & 6 & 25 & 2 & 30 & 3 & 35 & 4 \\
\hline 23-Aug & 480 & 33 & 385 & 29 & 80 & 11 & 30 & 3 & 15 & 1 \\
\hline 30-Aug & 80 & 11 & 135 & 18 & 170 & 21 & 115 & 16 & 60 & 7 \\
\hline
\end{tabular}

$H_{0}: \mu_{1}=\mu_{2}=\ldots=\mu_{r}$

$H_{1}: \mu_{1} \neq \mu_{2} \neq \ldots \neq \mu_{r}$

$\mathrm{R}: \chi^{2} \mathrm{~kW}>\chi^{2}{ }_{(0.90 ; 4)}$

Since $\chi^{2}{ }_{\mathrm{KW}}=4330.04$ that is greater than $\chi_{(0,90 ; 4)}^{2}=7.78$, then $\mathrm{H}_{\mathrm{O}}$ is rejected. 
Table 7. Non-parametric procedure to determine whether there is a difference between abundances of quahog larvae at two depths $(0.3$ and $1.6 \mathrm{~m})$ in Narragansett Bay during summer 1995.

\begin{tabular}{cccc}
\hline D-0.3 & RANK & D-1.6 & RANK \\
\hline 0 & 4.5 & 0 & 4.5 \\
0 & 4.5 & 0 & 4.5 \\
0 & 4.5 & 10 & 10.5 \\
0 & 4.5 & 20 & 17 \\
0 & 4.5 & 20 & 17 \\
0 & 4.5 & 20 & 17 \\
10 & 10.5 & 20 & 17 \\
10 & 10.5 & 30 & 25 \\
10 & 10.5 & 30 & 25 \\
20 & 17 & 30 & 25 \\
20 & 17 & 30 & 25 \\
20 & 17 & 40 & 33 \\
20 & 17 & 40 & 33 \\
20 & 17 & 50 & 39.5 \\
30 & 25 & 50 & 39.5 \\
30 & 25 & 50 & 39.5 \\
30 & 25 & 60 & 46.5 \\
40 & 33 & 60 & 46.5 \\
40 & 33 & 60 & 46.5 \\
40 & 33 & 60 & 46.5 \\
40 & 33 & 70 & 53.5 \\
40 & 33 & 70 & 53.5 \\
40 & 33 & 80 & 58.5 \\
40 & 33 & 80 & 58.5 \\
50 & 39.5 & 80 & 58.5 \\
60 & 46.5 & 90 & 65 \\
60 & 46.5 & 90 & 65 \\
60 & 46.5 & 90 & 65 \\
60 & 46.5 & 100 & 70 \\
60 & 46.5 & 100 & 70 \\
60 & 46.5 & 110 & 72 \\
70 & 53.5 & 120 & 74 \\
70 & 53.5 & 120 & 74 \\
80 & 58.5 & 150 & 77.5 \\
80 & 58.5 & 150 & 77.5 \\
80 & 58.5 & 190 & 81 \\
90 & 65 & 200 & 82 \\
90 & 65 & 210 & 84.5 \\
90 & 65 & 210 & 84.5 \\
\hline & & & \\
\end{tabular}


Table 7. Continued

\begin{tabular}{cccc}
\hline D-0.3 & RANK & D-1.6 & RANK \\
\hline 90 & 65 & 220 & 87 \\
100 & 70 & 250 & 91 \\
120 & 74 & 270 & 92 \\
130 & 76 & 310 & 95 \\
160 & 79 & 330 & 96 \\
170 & 80 & 400 & 100 \\
210 & 84.5 & 440 & 101 \\
210 & 84.5 & 480 & 103 \\
230 & 88 & 540 & 104 \\
240 & 89.5 & 584 & 106 \\
240 & 89.5 & 710 & 108 \\
290 & 93 & 720 & 109 \\
300 & 94 & 760 & 110 \\
340 & 98 & 770 & 111 \\
340 & 98 & 810 & 112 \\
340 & 98 & 850 & 113 \\
450 & 102 & 960 & 115 \\
550 & 105 & 980 & 116 \\
680 & 107 & 990 & 117.5 \\
920 & 114 & 1060 & 119.5 \\
990 & 117.5 & 1350 & 123 \\
1060 & 119.5 & 1410 & 124 \\
1070 & 121 & 1780 & 127 \\
1340 & 122 & 1800 & 128 \\
1660 & 125 & 1930 & 130 \\
1750 & 126 & 1950 & 131 \\
1830 & 129 & 2190 & 132 \\
2870 & 133 & 3270 & 134 \\
4410 & 137 & 3580 & 135 \\
4800 & 138 & 4260 & 136 \\
\hline & & &
\end{tabular}

$W_{A}=4617$

Mean rank $=4795.5 ;$ Standard deviation $=234.8$

$Z=\left(W_{A}-\right.$ Mean rank $) /$ Standard deviation $=-0.76 ; \quad Z_{\alpha / 2}=-1.96$

$R:|Z| \geq Z \alpha / 2$

Since $Z=-0.76$ does not fall in the rejection region, then $H_{O}$ is accepted. 
Table 8. Result of multiple regression, $x 1$, depth; $x 2$, moon phase; $x 3$, temperature; $x 4-x 7$, station.

Regression-Statistics

Multiple R

0.4444

R Square

0.1975

Adj. R Sq

0.1507

Std. Error

825.35

Observations

128

Analysis of Variance

\begin{tabular}{|c|c|c|c|c|c|}
\hline & df & $\begin{array}{c}\text { Sum of } \\
\text { Squares }\end{array}$ & $\begin{array}{l}\text { Mean } \\
\text { Square }\end{array}$ & $\mathrm{F}$ & $\begin{array}{c}\text { Significance } \\
\mathrm{F}\end{array}$ \\
\hline Regression & 7 & $2 \mathrm{E}+07$ & $3 E+06$ & 4.219 & 0.0003 \\
\hline Residual & 120 & $8.2 \mathrm{E}+07$ & 681197 & & \\
\hline Total & 127 & $1 E+08$ & & & \\
\hline
\end{tabular}

\begin{tabular}{lrrrrrr} 
& & & & & Lower & Upper \\
& Coefficients & Std. Error & t Statistic & P-value & $95 \%$ & $95 \%$ \\
\hline Intercept & 1106.9 & 624.792 & 1.7717 & 0.079 & -130.1 & 2344 \\
X1 & 127.72 & 145.902 & 0.8754 & 0.383 & -161.16 & 416.6 \\
X2 & -545.01 & 146.259 & -3.726 & $3 E-04$ & -834.6 & -255 \\
X3 & -35.008 & 26.7172 & -1.31 & 0.192 & -87.906 & 17.89 \\
x4 & 597.06 & 234.107 & 2.5504 & 0.012 & 133.55 & 1061 \\
X5 & 740.91 & 233.9 & 3.1676 & 0.002 & 277.81 & 1204 \\
X6 & 276.64 & 233.86 & 1.1829 & 0.239 & -186.38 & 739.7 \\
X7 & 231.3 & 233.725 & 0.9896 & 0.324 & -231.46 & 694.1
\end{tabular}


Table 9. Result of stepwise method, variable moon phase entered.

\begin{tabular}{lccccc} 
R_square $=0.0897$ & & & & \\
& DF & $\begin{array}{c}\text { Sum of } \\
\text { Squares }\end{array}$ & $\begin{array}{c}\text { Mean } \\
\text { Square }\end{array}$ & $F$ & Prob $>F$ \\
\hline Regression & 1 & $9 E+06$ & 9141420 & 12.42 & $6 E-04$ \\
Error & 126 & $9 E+07$ & 735887 & & \\
Total & 127 & $1 E+08$ & & &
\end{tabular}

\begin{tabular}{lcccc} 
Variable & $\begin{array}{c}\text { Parameter } \\
\text { Estimate }\end{array}$ & $\begin{array}{c}\text { Standard } \\
\text { Error }\end{array}$ & F & Prob $>F$ \\
\hline Intercept & 772.73 & 110.75 & 6.9775 & 1 E-10 \\
Moon & -535.53 & 151.94 & -3.5245 & $6 \mathrm{E}-04$ \\
\hline
\end{tabular}


Table 10. Result of stepwise method, variable stations entered. $x 1$, moon phase; $x 2-x 5$, stations.

R sqūare $=0.1809$

\begin{tabular}{|c|c|c|c|c|c|}
\hline & DF & $\begin{array}{c}\text { Sum of } \\
\text { Squares }\end{array}$ & $\begin{array}{c}\text { Mean } \\
\text { Square }\end{array}$ & $\mathrm{F}$ & Prob $>F$ \\
\hline $\begin{array}{l}\text { Regression } \\
\text { Residual } \\
\text { Total }\end{array}$ & $\begin{array}{c}5 \\
122 \\
127\end{array}$ & $\begin{array}{l}2 E+07 \\
8 E+07 \\
1 E+08\end{array}$ & $\begin{array}{c}3685609 \\
683895\end{array}$ & 5.389 & 2E-04 \\
\hline Variable & $\begin{array}{c}\text { Parameter } \\
\text { Estimate }\end{array}$ & $\begin{array}{c}\text { Standard } \\
\text { Error }\end{array}$ & $F$ & Prob $>F$ & \\
\hline Intercept & 394.16 & 184.02 & 2.14193 & 0.034 & \\
\hline$x 1$ & -546.7 & 146.54 & -3.7304 & $3 E-04$ & \\
\hline$x 2$ & 615.19 & 234.16 & 2.62723 & 0.01 & \\
\hline$x 3$ & 753.65 & 234.16 & 3.21854 & 0.002 & \\
\hline$x 4$ & 288.04 & 234.16 & 1.23009 & 0.221 & \\
\hline$\times 5$ & 235.96 & 234.16 & 1.00769 & 0.316 & \\
\hline
\end{tabular}


Figure 2. Distribution of bivalve larvae at early stage associated with temperature in Conimicut $\mathrm{Pt}$.

—- : temperature; - — : quahog larvae; + ; other bivalve larvae; —— : total bivalve larvae. 


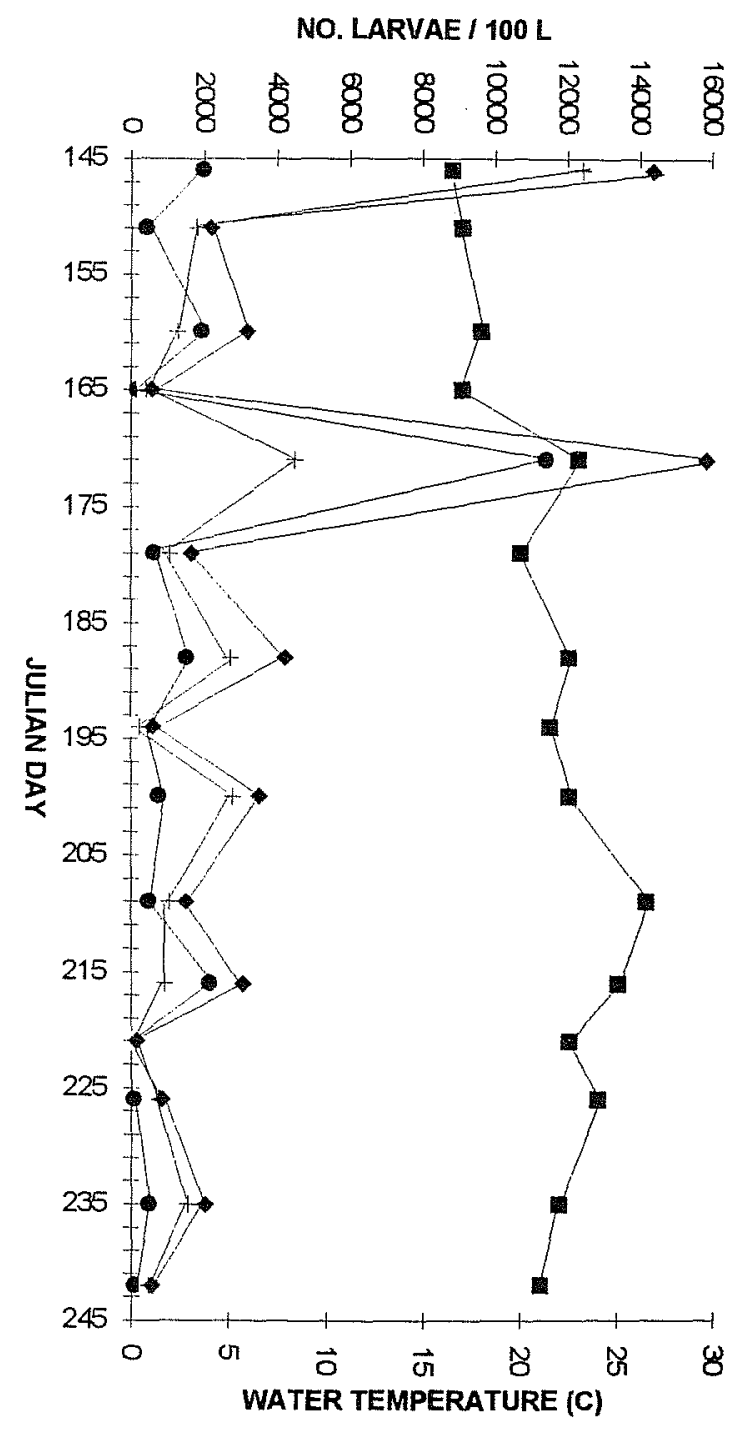


Figure 3. Distribution of bivalve larvae at late stage associated with temperature in Conimicut $\mathrm{Pt}$.

- : temperature; —— : quahog larvae; + ; other bivalve larvae; —— : total bivalve larvae. 


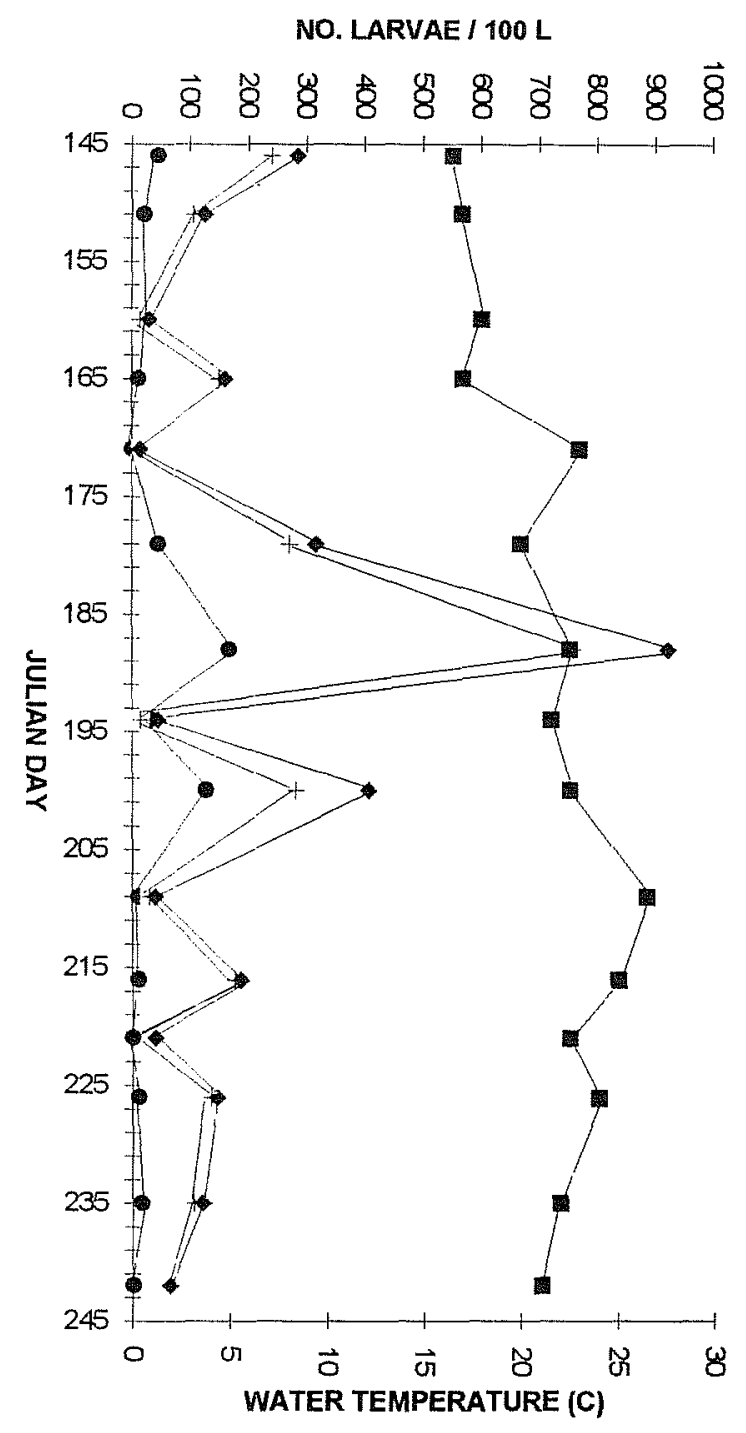


Figure 4. Distribution of bivalve larvae at early stage associated with temperature in Rocky Pt.

- - : temperature; —- : quahog larvae; +; other bivalve larvae; - : : total bivalve larvae. 


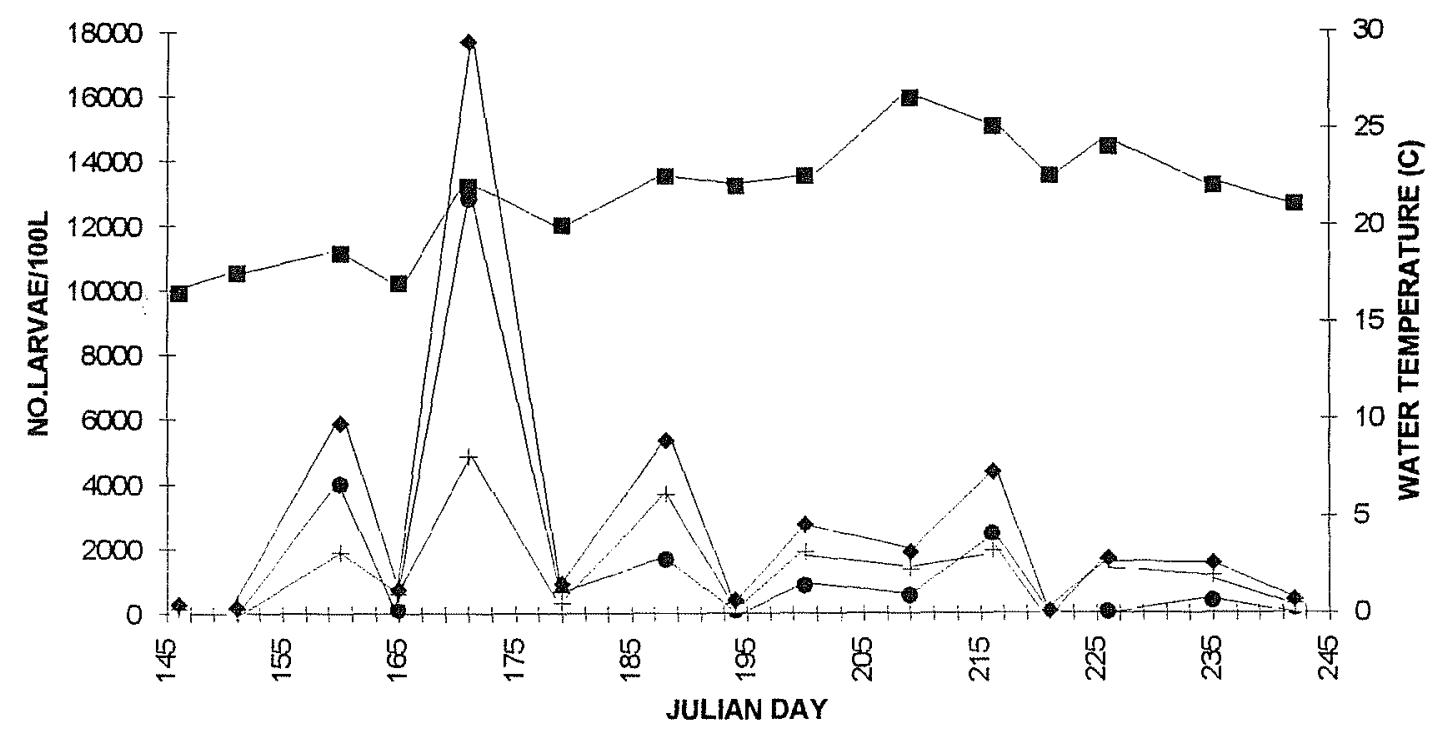


Figure 5. Distribution of bivalve larvae at late stage associated with temperature in Rocky Pt.

- - : temperature; —— : quahog larvae; + ; other bivalve larvae; — - : total bivalve larvae. 


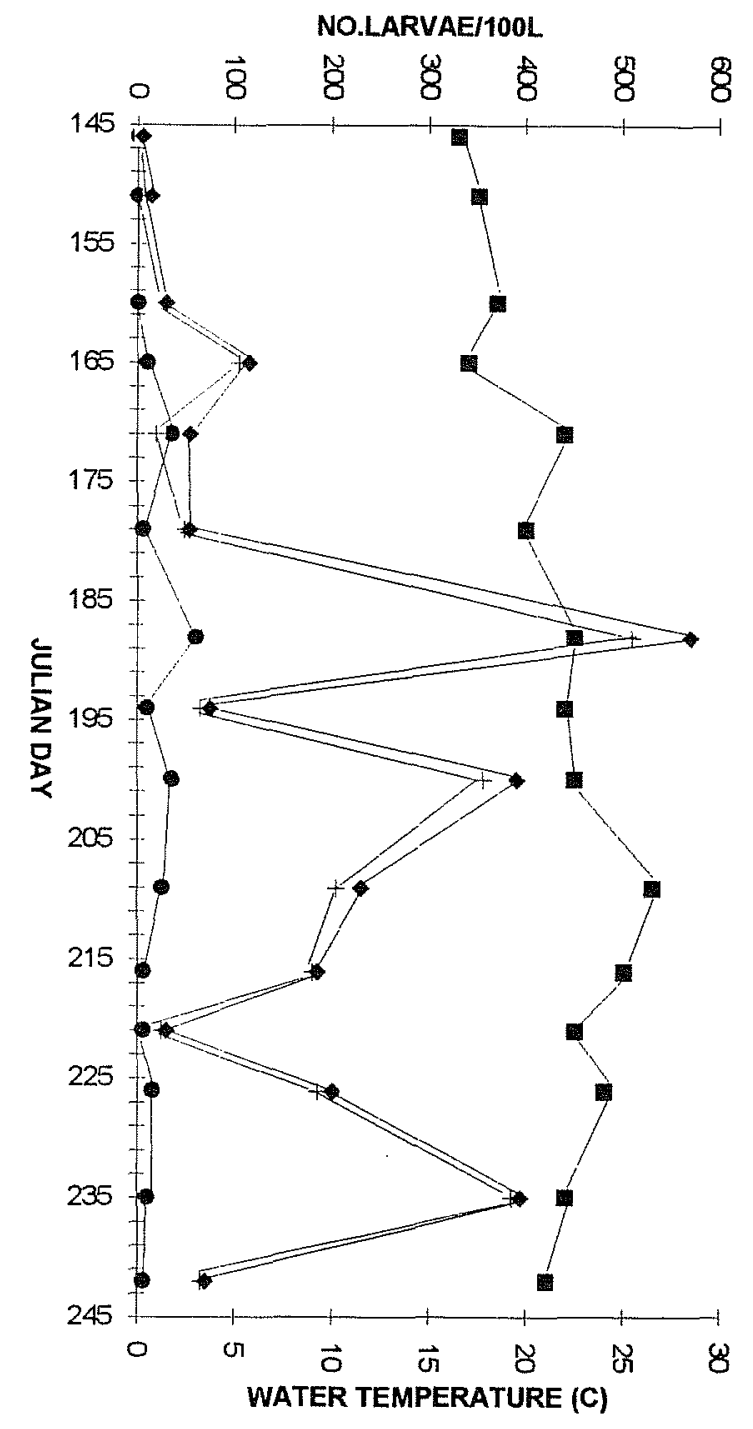


Figure 6. Distribution of bivalve larvae at early stage associated with temperature in Warwick Pt.

—- : temperature; —— : quahog larvae; + ; other bivalve larvae; — : total bivalve larvae. 
NO.LARVAE/100L
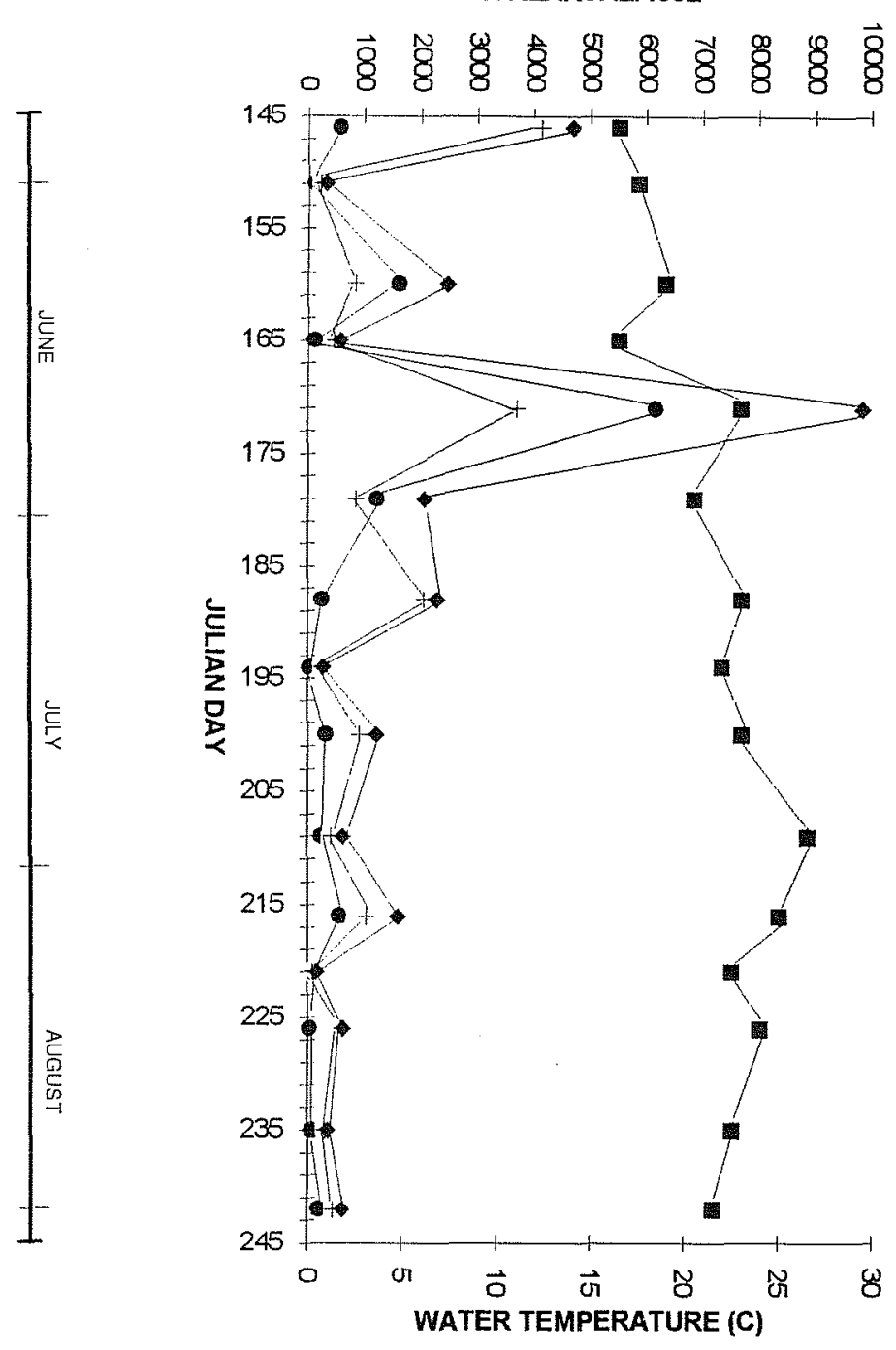
Figure 7. Distribution of bivalve larvae at late stage associated with temperature in Warwick Pt.

—- : temperature; —— : quahog larvae; + ; other bivalve larvae; — - : total bivalve larvae. 

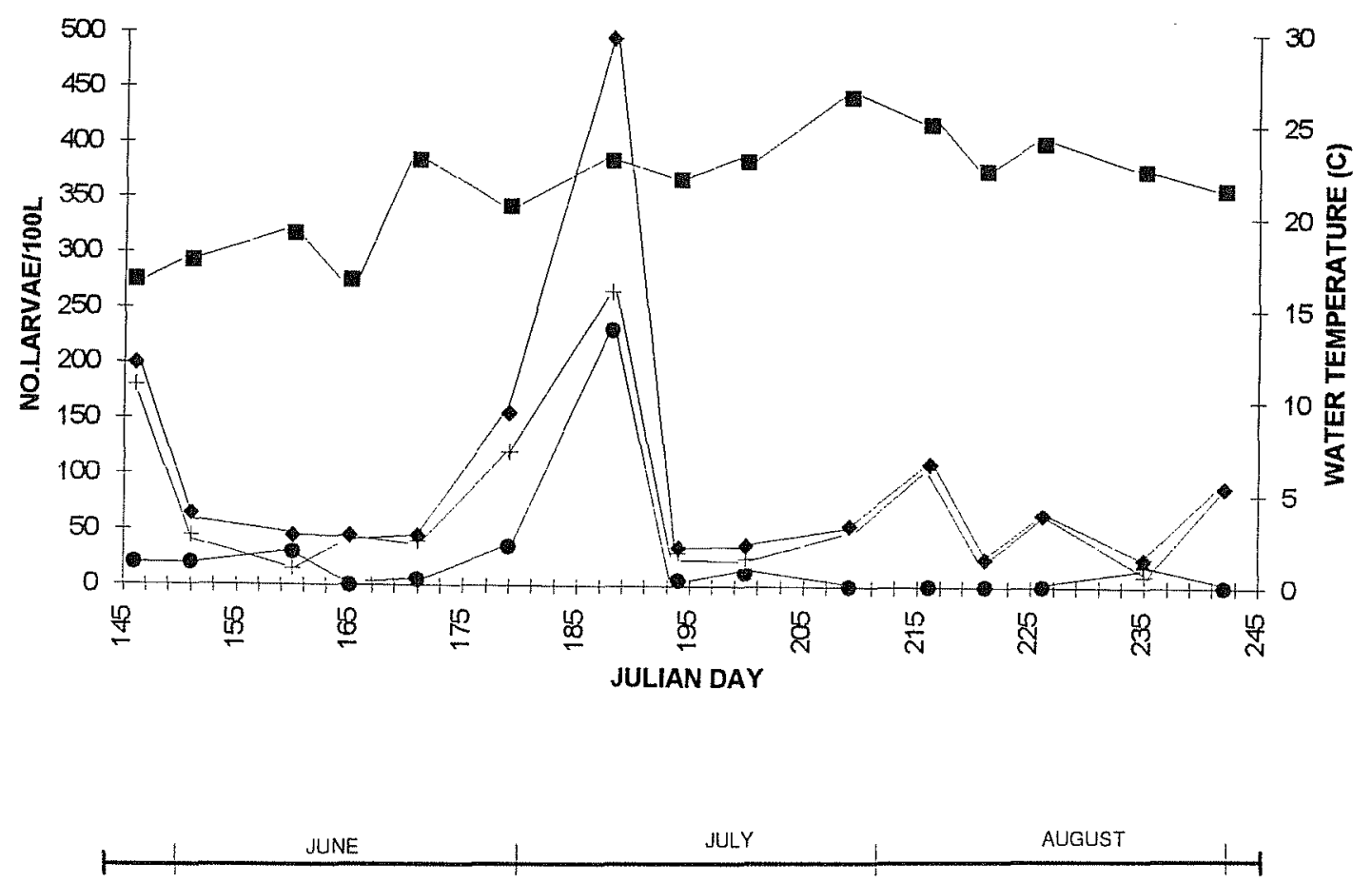
Figure 8. Distribution of bivalve larvae at early stage associated with temperature in Mt. View.

$\longrightarrow$ : temperature; —— : quahog larvae; + ; other bivalve larvae; — - : total bivalve larvae. 


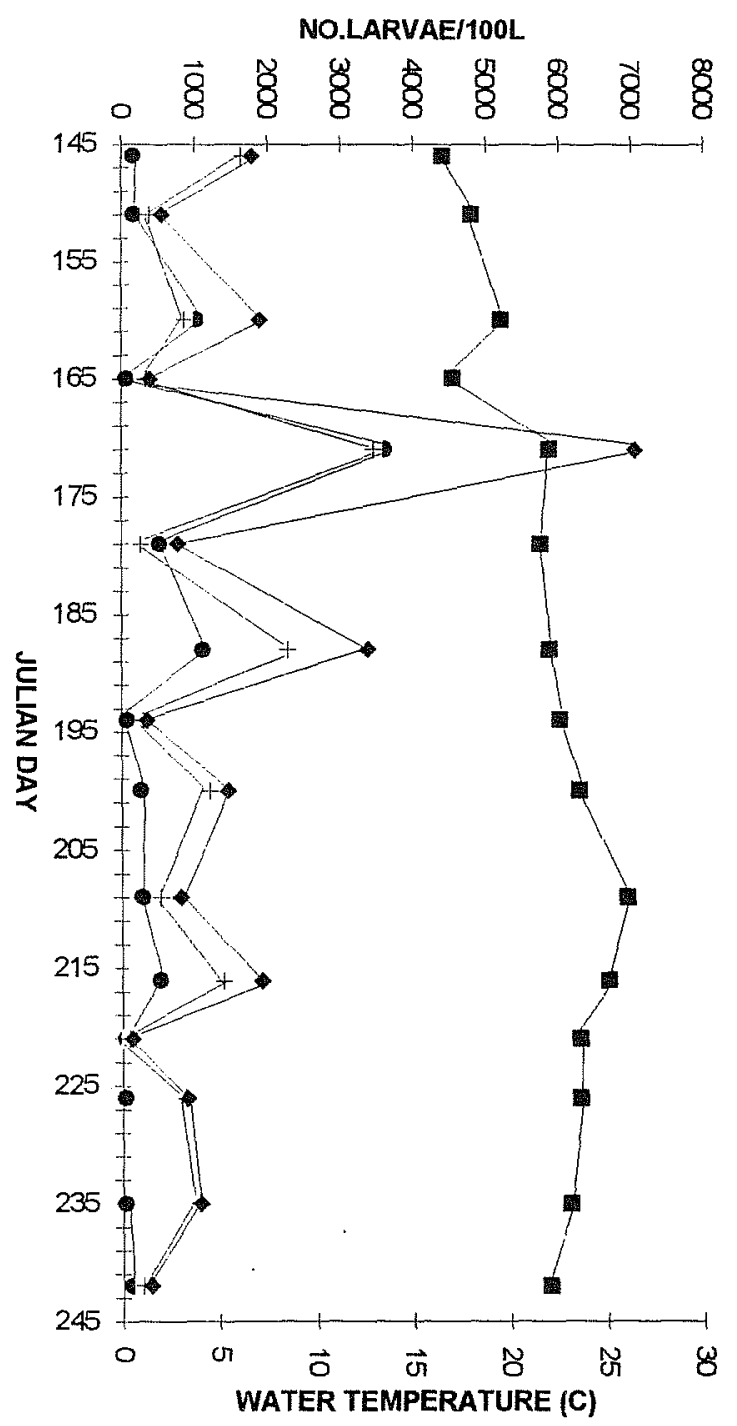


Figure 9. Distribution of bivalve larvae at late stage associated with temperature in Mt. View.

- - : temperature; _- : quahog larvae; + ; other bivalve larvae; — : total bivalve larvae. 


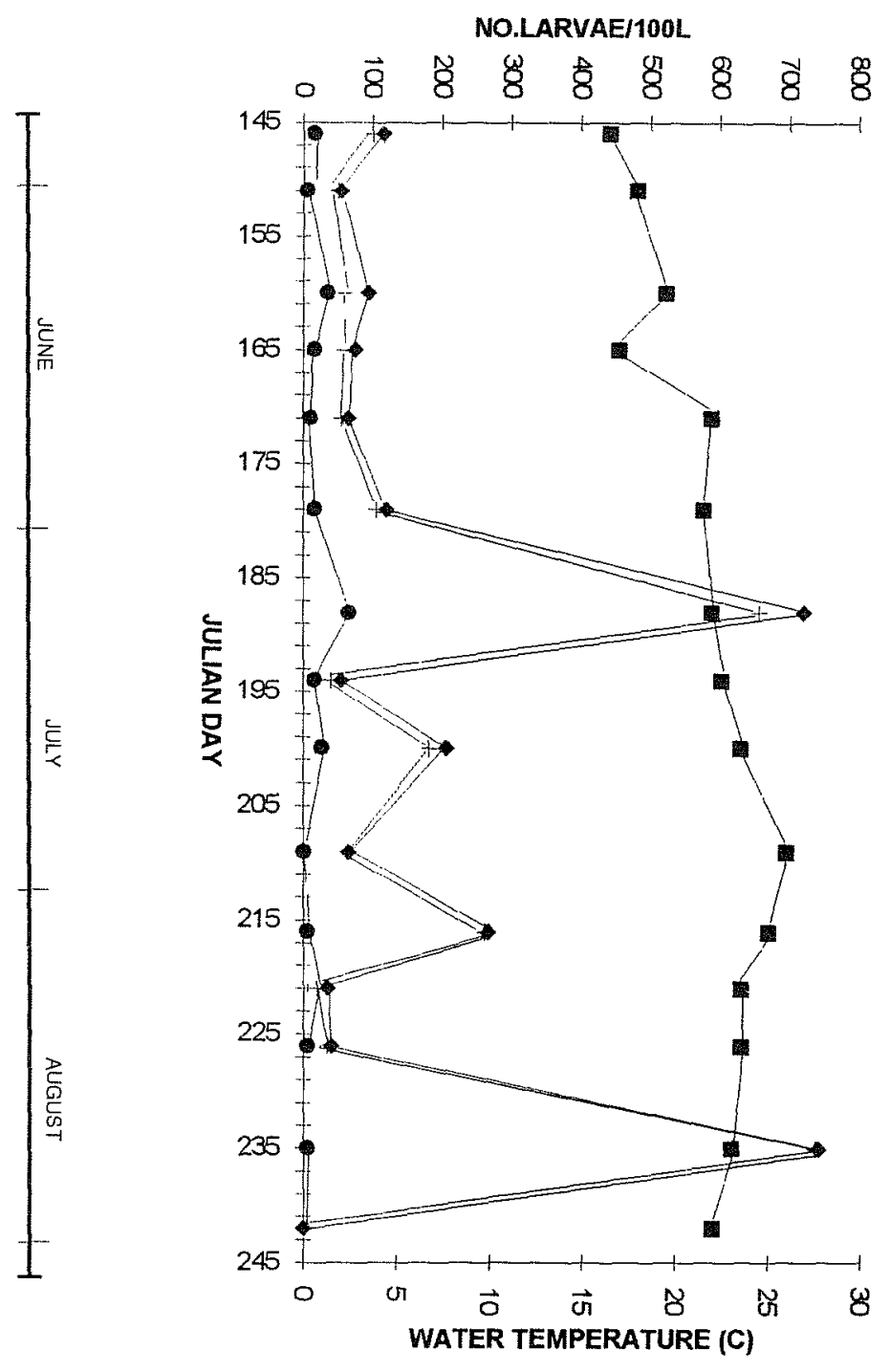


Figure 10. Distribution of bivalve larvae at early stage associated with temperature in Wickford.

—- : temperature; —— : quahog larvae; + ; other bivalve larvae; — : : total bivalve larvae. 

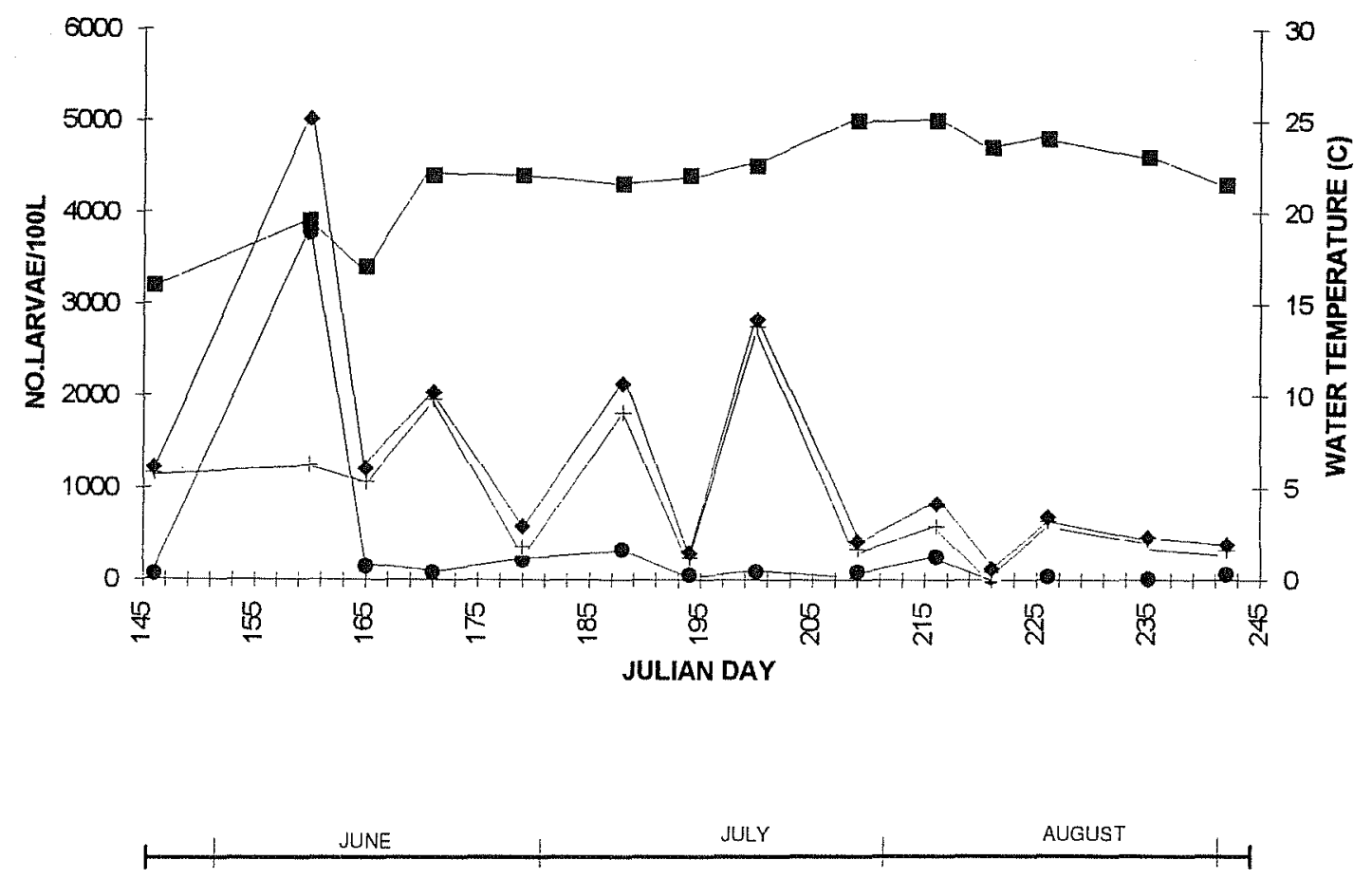
Figure 11. Distribution of bivalve larvae at late stage associated with temperature in Wickford.

— : temperature; —— : quahog larvae; + ; other bivalve larvae; — : : total bivalve larvae. 

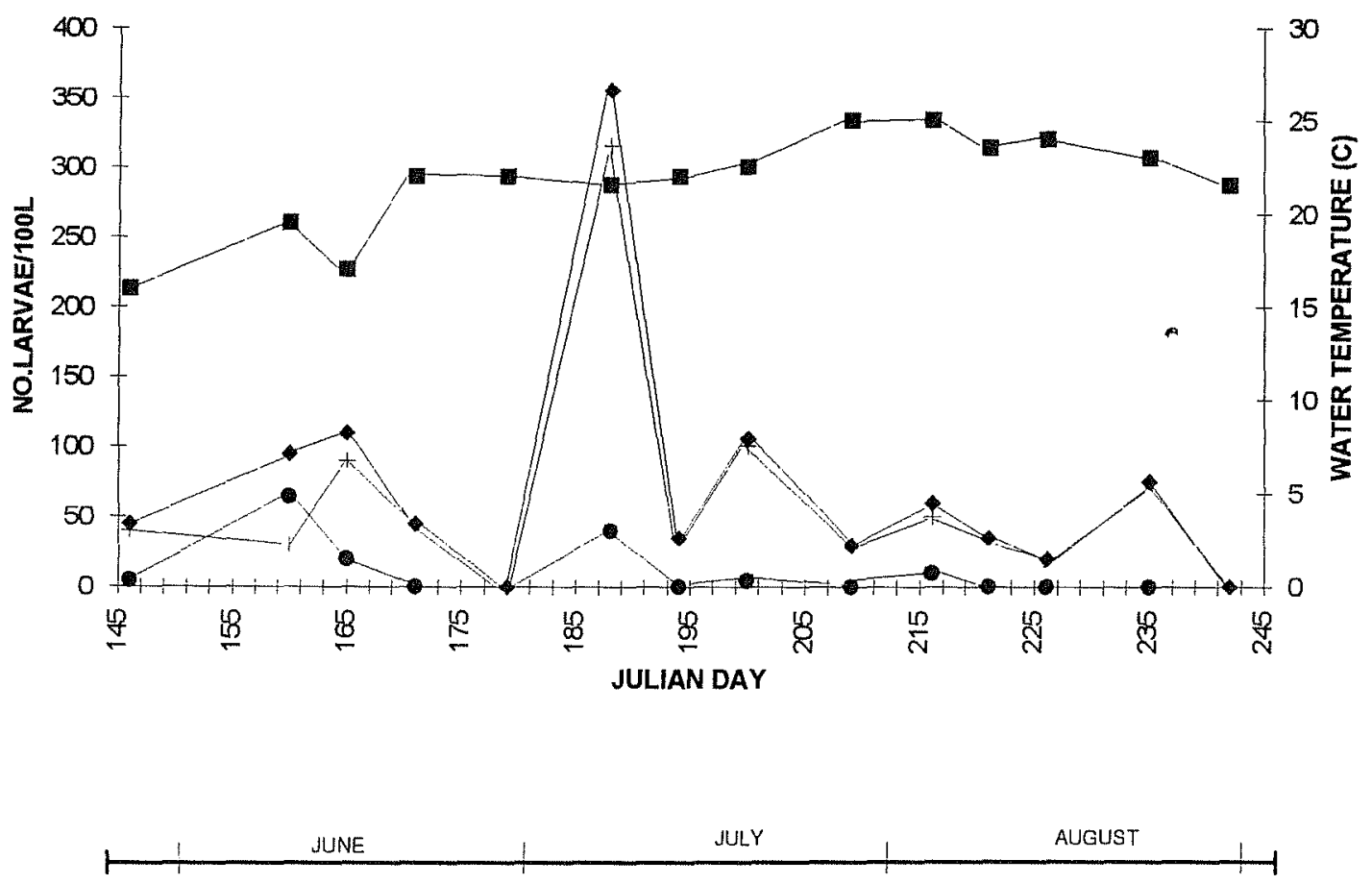
FIGURE 12. Distribution of bivalve larvae associated with moon phase in Narragansett Bay.

$\ldots$ - quahog larvae ; —— : other bivalve larvae; —— : total bivalve larvae. 

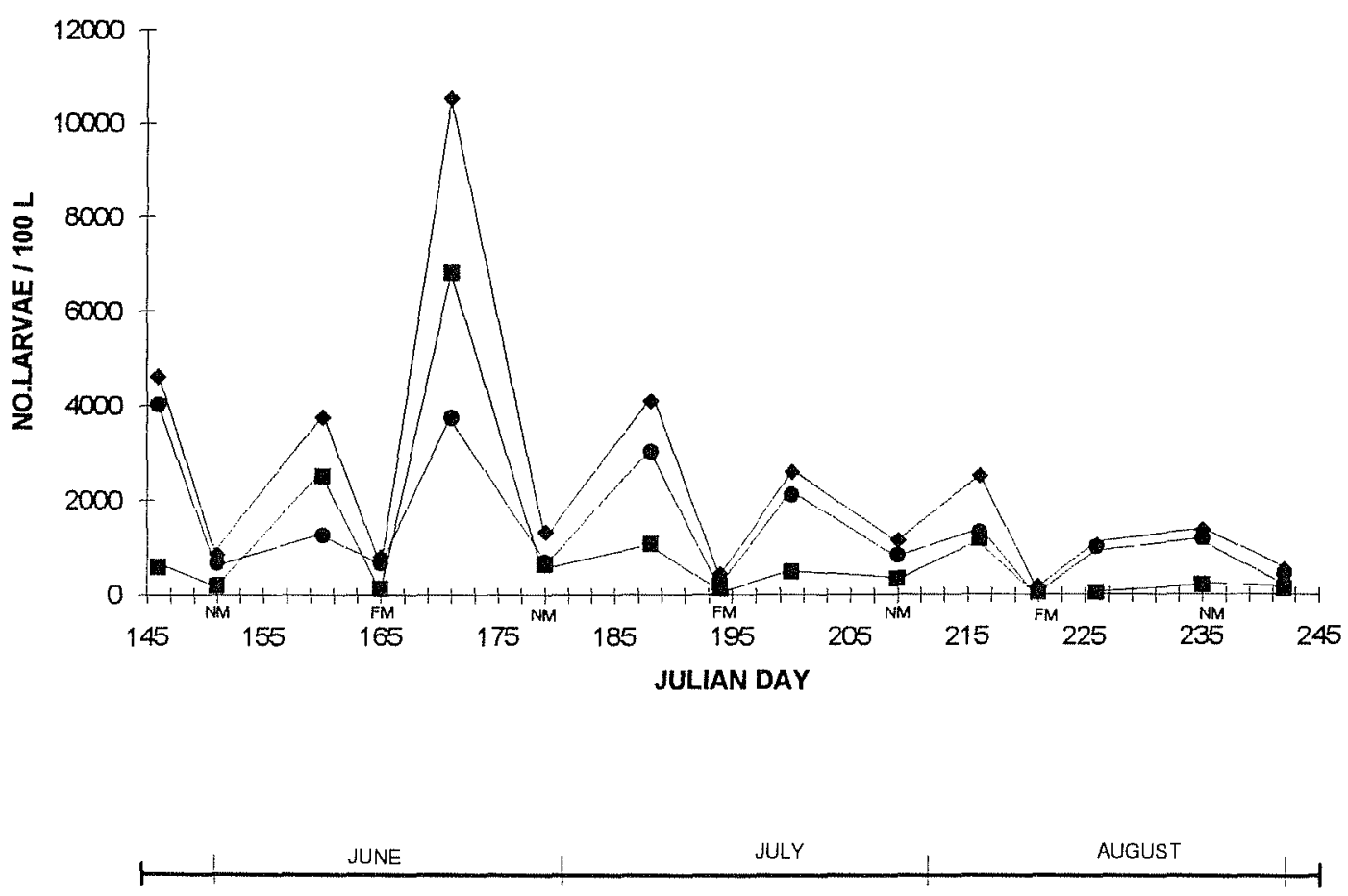
FIGURE 13. Relationship between abundance of quahog larvae and water temperature at Conimicut Pt. during summer 1995. 


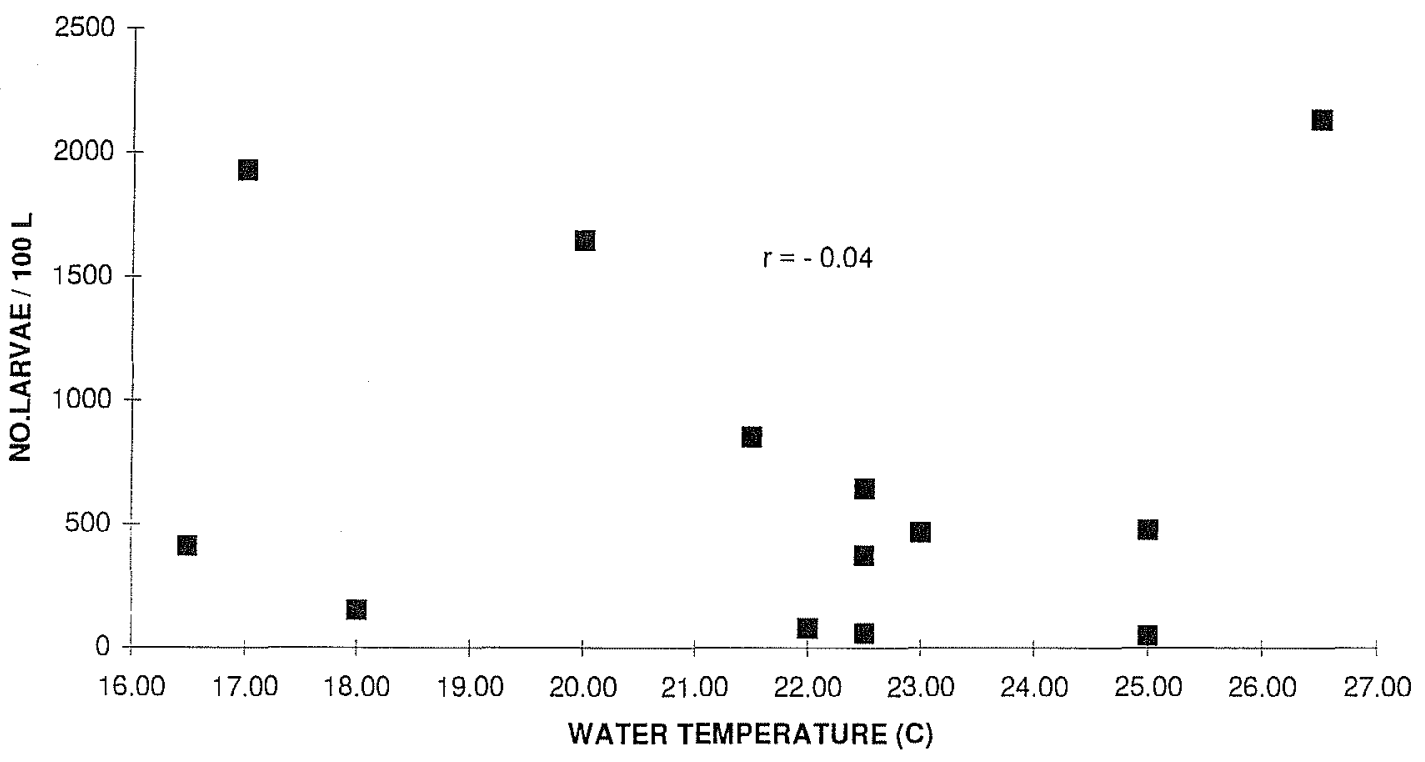


FIGURE 14. Relationship between abundance of quahog larvae and water temperature at Rocky Pt. during summer 1995. 


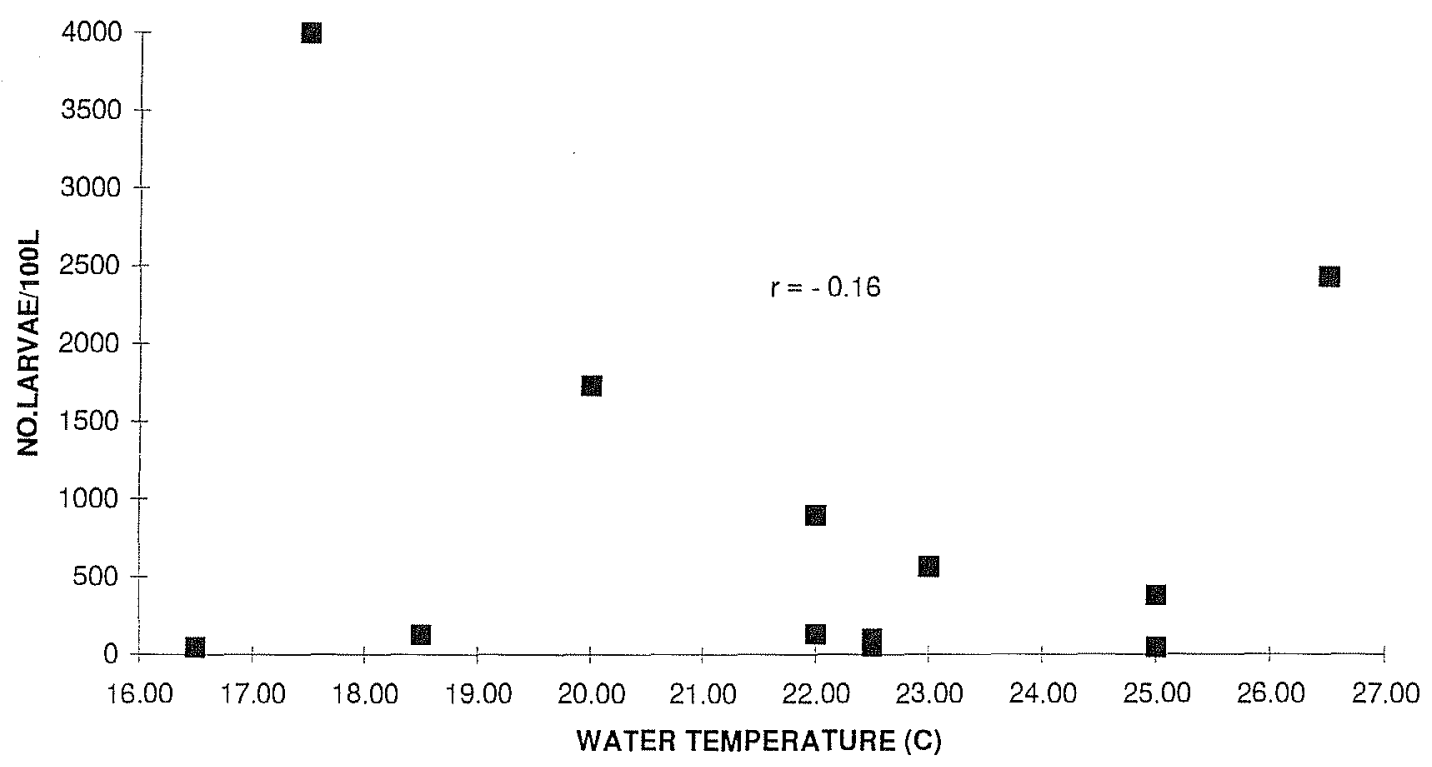


FIGURE 15. Relationship between abundance of quahog larvae and water temperature at Warwick Pt. during summer 1995. 


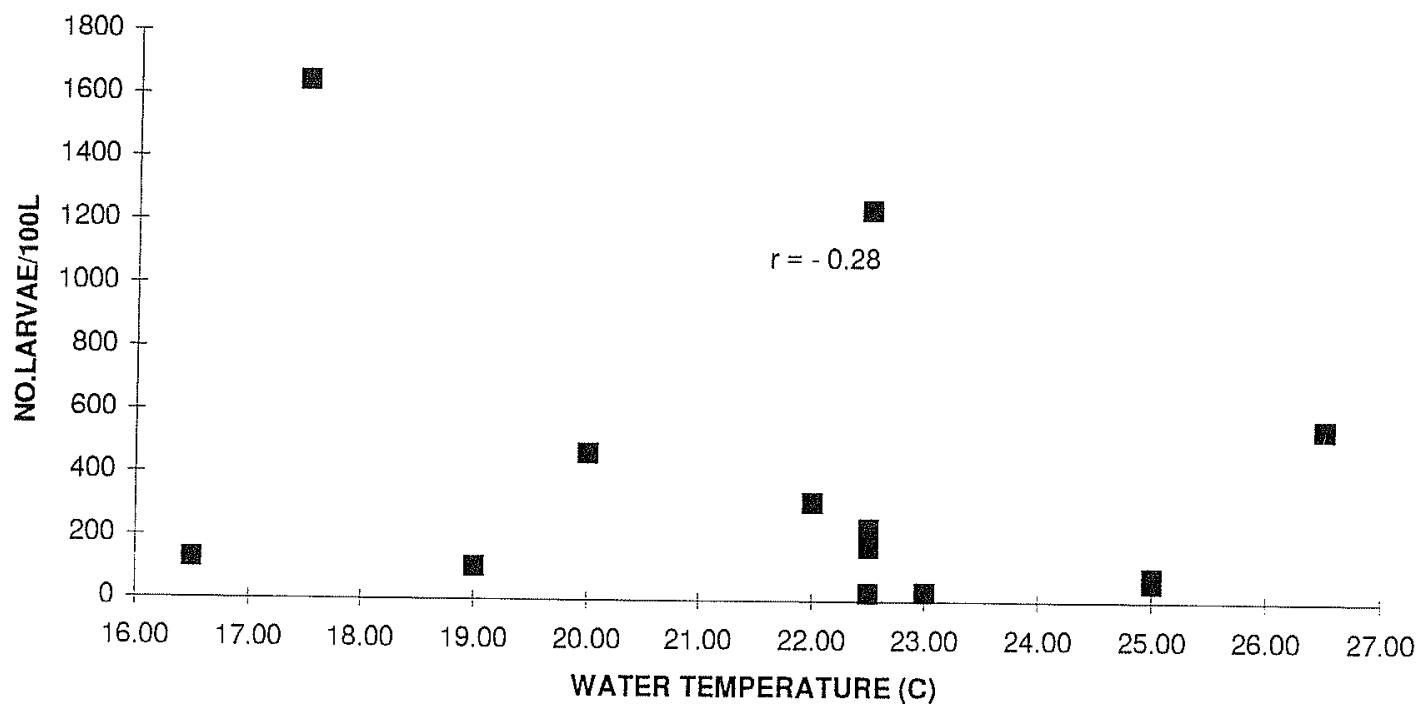


FIGURE 16. Relationship between abundance of quahog larvae and water temperature at Mt. View during summer 1995. 


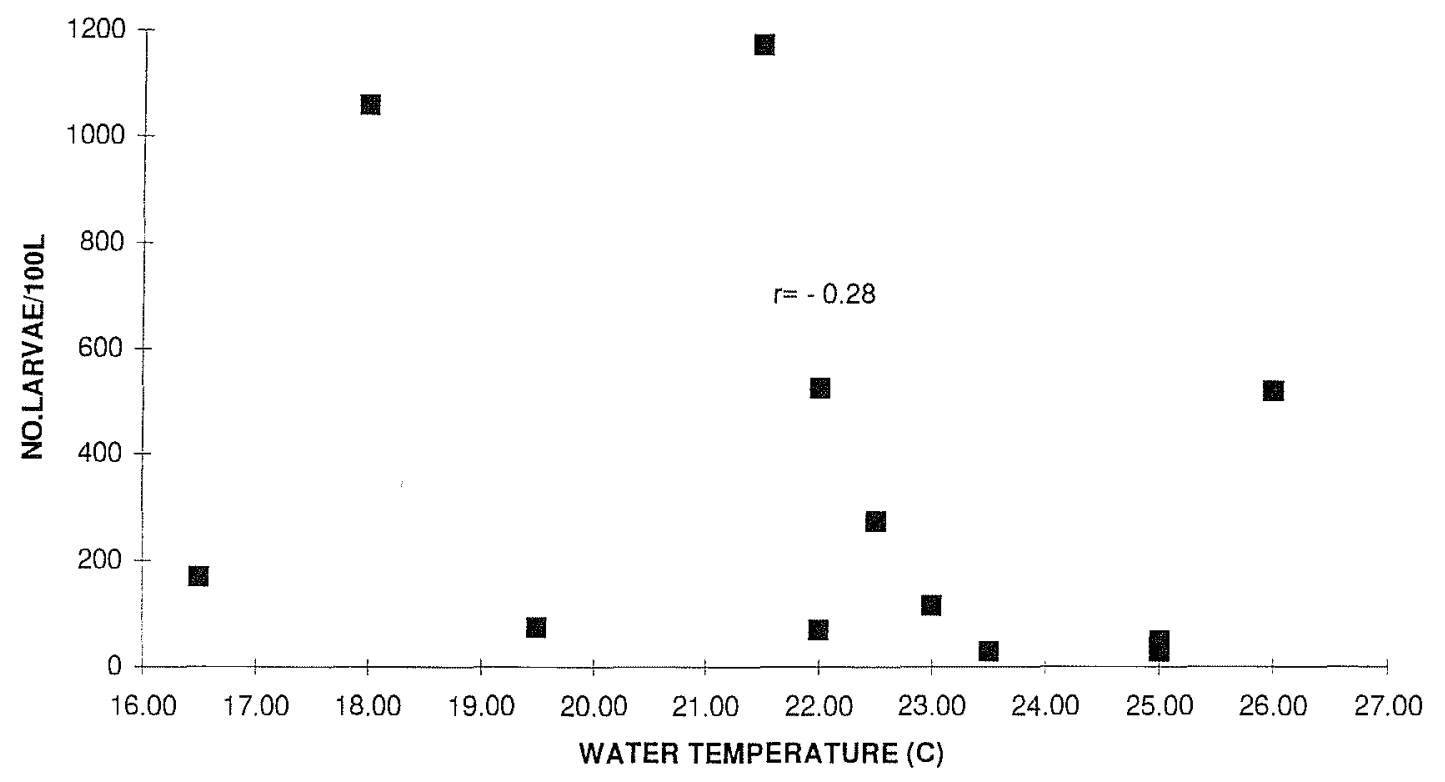


FIGURE 17. Relationship between abundance of quahog larvae and water temperature at Wickford during summer 1995. 


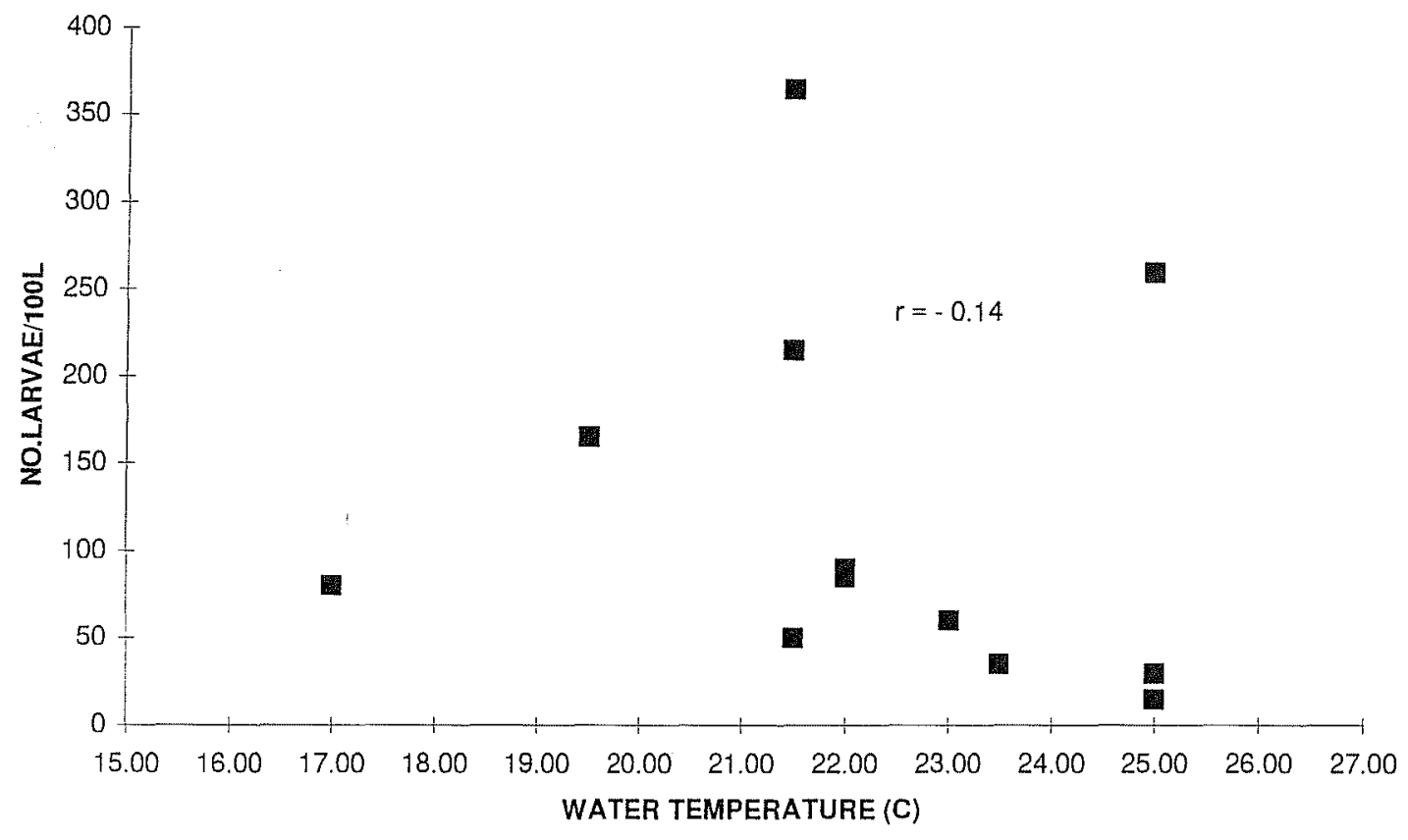




\section{DISCUSSION}

\section{Distribution of Quahog Larvae}

The temporal distribution of quahog larvae may describe the events of the spawning pattern. This study found that quahog larvae at early stage along a North - South transect occurred weekly from May to August. The larvae reached peak abundances on June 20 at all sampling stations, except Wickford. These results are consistent with the results of Landers (1954) and Rice and Goncalo (1995) who reported that peak abundances of bivalve larvae in Wickford and Greenwich Bay occurred on June 11 and on June 14, respectively. The patterns of summer larval abundances indicated that Narragansett Bay quahogs commenced spawning throughout summer months once water temperature rises, and released gametes at least once a week. Intense spawnings, which might relate to major peak abundances of the swarming larvae, could be triggered by increase water temperature to about $20^{\circ} \mathrm{C}$, in mid June.

The reproductive cycle in Narragansett Bay quahogs has been addressed by Diamond (1981). She discovered that two cycles of reproductive activity in quahog population occurred in summer and fall, however, rapid maturation of the gonads which subjects to intense spawning was between April and June. Individuals of this population appear to spawn partially. According to Loosanoff (1937a), an individual quahog does not discharge all of its eggs or sperm at one time, but it continues at intervals of a few days or perhaps weeks to complete the spawning. The male usually spawns first, then stimulates other males and later the females also to spawn (Carriker, 1961). Increased water temperature, coupled with phytoplankton blooming, is considered to be of primary importance 
in controlling the spawning (Loosanoff, 1937a, 1937b; Loosanoff and Davis, 1951; Carriker, 1961; Nelson, 1987).

Differences of the temporal pattern of spawning at different sites in a certain estuary may be due to the variations of water temperature. Landers (1954) reported that quahogs inhabiting a shallow water spawned earlier than those in a deeper one. Warming of the exposed bottom in the shallower water triggers release of gametes. This hypothesis may apply in the present study in which that temporal distribution of the larvae in Wickford showed different pattern than in upper bay stations. Both larval stages (i.e., early stage and late stage) in Wickford reached their maximum densities on June 9, earlier than those in other sites. Presumably, there was a major peak of early stages a couple of weeks earlier accounting for the peak of the late stage on June 9 . The peak abundances of the larvae in Wickford are likely influenced by the spawner stock inhabiting shallow area. Knowledge of potential excursion of the larvae may facilitate the identification of spawner stock areas in which larvae originate.

Late stage larvae reached peak abundances on July 7 at all sampling stations, except Wickford. If we are to assume that the late stage larvae on July 7 are at the same cohort as the early ones on June 20 , then the duration of planktonic life of quahog larvae in Narragansett Bay is about 2 - 3 weeks. According to Loosanoff and Davis (1951), at the age of approximately 12 days or at pediveliger stage, the quahog larvae become competent and ready to settle. We, therefore, can deduce that quahog larvae in Narragansett Bay are ready to settle at least $2-3$ weeks after fertilization. An intense settlement can occur in the middle of summer as the late stage larvae reached the major peak mostly in July. It appears that once intense settlement occurs, the rate of settlement then gradually declines. 
Spawning of bivalves may also coincide with lunar cycles. Intense spawnings of oysters and quahogs and peak abundances of the larvae in Little Egg Harbor occurred concurrently with neap tides (Loosanoff and Nomejko, 1951; Carriker, 1961). During neap tides as tidal amplitude is low, exchange with cooler ocean water results in warmer bay water temperature, thus, inducing intense spawning. On the other hand, high tidal amplitude during spring tides give rise to high tidal exchange which probably accounts for the loss of the larvae. The result of the present study appeared to be consistent with those previous studies that more larvae were observed in the water column during neap tides than during spring tides. Peak abundances of early and late stage larvae occurred coincidentally in neap tides, therein, tidal amplitudes were between 0.55 and 2.2 feet lower than those in spring tides (Chinman and Nixon, 1985; Spaulding et al., 1990).

The second aspect of larval distribution to be discussed is spatial distribution which tends to be patchy and shows a tendency of decreasing number from upper to lower part of Narragansett Bay. In previous studies on plankton dynamics, Smayda (1988) and Durbin and Durbin (1988) reported that bivalve larvae were several fold more abundant in the Providence River and Upper Bay than those in Wickford. The results of the present study were consistent with these. Regardless of the phase of tidal flows, densities of the larvae in Upper Bay stations were always higher, about 1.5 times, than those in Upper West Passage stations. The total bivalve larvae in Upper Bay mostly composed of quahog larvae which decreased in numbers as sampling encountered further down the Bay; while those in Upper West Passage tended to be dominated by larvae of other bivalve species. Presumably, the location of the spawner stock and water circulation of the Bay play an important role in determining this larval dispersion (Carriker, 1951). 
According to Okubo $(1980,1994)$ and Scheltema (1984), the dispersion of the larvae is affected by not only tidal and non-tidal currents but also by turbulent diffusion. Tidal and non-tidal currents, on one hand, are capable of advecting the larvae horizontally from the parent beds. During transport, some of the larvae are trapped in the boundaries (Andrews, 1983; Scheltema, 1984; Okubo, 1994). At the same time, turbulent flow causes the larvae to disperse with respect to one another, giving rise to a distribution in which there is a concentration gradient decreasing from the center of a patch of the larvae outward (Okubo, 1980; Scheltema, 1984). The implication is that fewer numbers of larvae are apparent at increasing distance from the spawner stock beds. Stoner et al. (1996) noted that more queen conch larvae were concentrated in the area near the center of the source of the larvae.

By assuming that those concepts of centroid-like dispersion can be applied to the present study on the distribution of bivalve larvae, the closer the location of the swarming larvae to the spawner stock area, the more the larvae are concentrated in that location. In contrast, the longer the radius of the location of larvae from the parent bed, the less the larvae are found in that location. It, then, appears that Upper Bay is close to the area in which adult quahogs - as the source of the larvae - are abundant. Upper West Passage is likely far from the spawner stock area; although, it might be dominated by communities of other species of bivalve. Thus, by taking Providence River which has been long known being the major spawner stock area of Mercenaria mercenaria population as the center of larval dispersion, the concept of centroidlike dispersion might support the data indicating that more quahog larvae stay in Upper Bay since its location is close to Providence River. On the other hand, benthic communities in Upper and Middle West Passage are dominated by Mulinia lateralis, Pitar morrhuana, and Macoma tenta (Sparsis et al., 1993). 
Mytilus edulis is also one of the bivalves distributing more in the lower part of the Bay; and the area near Prudence Island is the northernmost region of the occurrence of this species (Nelson, 1984). Therefore, the distribution of bivalve larvae along a North - South transect in Narragansett Bay appears to coincide with adult distribution.

In addition to that, tidal-induced current dominating water circulation is a potential means to displace the larvae from the parent beds, and may contribute to the patchiness of larval dispersion along a longitudinal axis of the estuarine system. Tidal excursion of approximately $1-4.4 \mathrm{~km}$ in the Bay (Turner, 1984; Spaulding et al. 1990; Turner et al., 1991a, 1991b) is responsible for displacing quahog larvae from Providence River into as far as Upper Bay in one ebb tide, and they can be carried back into the spawner stock area during flood tide. With respect to this phenomenon, it is unlikely that larvae from Providence River can be transported to Upper West Passage, and it seems that there is no free larval exchange between those two areas. Upper layer non-tidal circulation, however, appears to be a supplementary means to advect the larvae beyond the tidal excursion; thus, small numbers of the larvae can be drifted to lower parts of the Bay. It is somewhat difficult to detect the larval transport in this case, unless hydrodynamic model of the Bay and dye studies are performed to explain the process of the transport.

Turner et al. (1991a, 1991b) reported that it took one week for dye released from Providence River to travel into Upper West Passage, a distance of about $20 \mathrm{~km}$. Accordingly, the concentrations of dye declined seaward. Kremer (1975) noted that after two tidal cycles only $2.3 \%$ of the Upper Bay moved into the element Upper West Passage, 6.2 \% into Greenwich Bay, $9.7 \%$ into Upper East Passage, $6.2 \%$ into Providence River, and $74 \%$ remains in Upper Bay. The results of those hydrodynamic studies seem to imply that larvae from 
Providence River are mostly retained in Upper Bay, and only small fraction of the larvae can be transported into West Passage. In conclusion, it is not surprising that samples of quahog larvae collected during summer 1995 were patchy and more concentrated in upper portions of the Bay.

The effects of filter feeding of adult quahogs may also give a considerable contribution to the patchiness of larval distribution. As a filter feeder, quahogs are able to filter their own larvae (Rice and Goncalo, 1995). As a consequence, densities of the larvae were low in the location in which close to the area of dense adult quahogs (Rice and Goncalo, 1995), and might lead to a relatively high mortality. However, the present study seems not to support their evidence. The possible explanation is that the former study dealt with the area having a shallow depth, while the latter dealt with the area having a deeper depth. The differences of the topography may partly contribute to describe the patchiness of larval distribution due to the effect of benthic predation. Larvae close to or on the bottom are subject to greater predation by filter feeders than those staying in the upper layer (Carriker, 1961). Thus, a study conducted in an area with shallow depths may better represent the real condition of biological interaction on the bottom habitat than the one conducted in the area with deeper depth in which samples collected from upper layer. The depth of the study area within which Rice and Goncalo (1995) conducted sample collections is about $2.0 \mathrm{~m}$. In their study, samples were collected from 0.3 and $1.6 \mathrm{~m}$ which are relatively close to the bottom and might well explain the condition of the relation between adult assemblages and larval supply. The average depth of the present study area is approximately $5.6 \mathrm{~m}$ (Chinman and Nixon, 1985), and samples were taken from 0.3 and $1.6 \mathrm{~m}$ which are considered to be a surface layer. 
Mortality

On the basis of the ratio of early and late stage larvae from the same cohort -assumed that the planktonic life is about 2 to 3 weeks-, the mortality of quahog larvae would be between 80 and $99 \%$ (Table 4). This finding seems to be reasonable. Carriker (1961) found only about $2 \%$ of quahog larvae in Little Egg Harbor recruited into the settlement phase and metamorphosis, thus becoming juvenile clams. In Greenwich Bay, Rice and Goncalo (1995) calculated that $95 \%$ of bivalve larvae were lost due to natural mortality.

High mortality at early life stages is common since the animal at this stage is prone to environmental changes and predation. However, quahog larvae are tolerant to a wide range of physical conditions (Carriker, 1961). The quahog larvae may survive in the salinity ranging from 15 to $35 \mathrm{ppt}$, and in the water temperature between 10 and $30^{\circ} \mathrm{C}$ (Carriker, 1961; Davis, 1969). Thus, in a favorable environment which physical condition meets the requirements for survival, the source of quahog larval mortality seems to be due to the predation. There are considerable amounts of predators, which includes adult filter feeders, fish, gastropods, crabs as well as crab larvae (Carriker, 1961; McConaugha, 1985; Rice, 1992).

The larvae of brachyuran crabs are a potential predator of bivalve larvae (Sastry, 1983; McConaugha, 1985). Pagurus longicarpus prey upon the oyster veligers (McConaugha, 1985). Laboratory observation showed that Neopanope texana is a ferocious predator of young hard clam, however, the predation is considered to be size-dependent (Landers, 1954). In Narragansett Bay, larvae of Neopanope texana, Neopanope sayi, and Cancerspp. were abundant in summer months (Hillman, 1964; Trifan, 1987). During the plankton sampling of summer 1995, there were significant amounts of unidentified crab larvae in the 
Bay. Therefore, it is possible that high mortality of quahog larvae during the course of sample collection was partially due to the predation by crab larvae.

\section{Statistical Analyses}

Lack of a linear relation between water temperature and larval abundance may be better explained by looking at the nature of the diagram of those variables. A qualitative evaluation shows that the densities of the larvae were low at water temperatures of less than $20^{\circ} \mathrm{C}$. Intense spawning occurred as water temperature rose to $20^{\circ} \mathrm{C}$ and was characterized by major peaks of larval abundances. However, the densities then declined following the peak abundances as water temperature increase to above $20^{\circ} \mathrm{C}$. It appears that a water temperature of $20^{\circ} \mathrm{C}$ is a threshold to stimulate the spawning, thus, levels of water temperature beyond the threshold give rise to less intense spawning and low larval densities.

Multiple regression analysis showed that only $20 \%$ of the variability of larval abundances can be attributed to the linear model. A large portion of the variability is still left unexplained. Therefore, result of linear correlation and multiple regression analyses suggest that linear model does not seem to be relevant for evaluating the temporal and spatial variations of quahog larvae due to the given physical factors. 


\section{SUMMARY}

1. Peak abundance of early stage larvae occurred on June 20 (171st Julian day) in all sampling stations, as water temperature reached $20^{\circ} \mathrm{C}$; except in Wickford, the peak occurred 11 days earlier.

2. The peak of late stage larvae occurred 17 days later indicating that the duration of planktonic life is about $2-3$ weeks.

3. The differences in the pattern of larval distribution between upper bay stations and Wickford may be attributed by the variation of spawning biomass distribution, due to the differences in water temperature and distribution of the spawner stock area in which larvae originate.

4. There was a tendency of decreasing gradient of larval abundances from Upper Bay stations to Upper West Passage due to tidal and possibly nontidal currents.

5. The rate of mortality of quahog larvae was found between 80 and $99 \%$.

6. The analyses of correlation and multiple regression showed that a linear model only gave little contribution to the variation of quahog larval abundances in Narragansett Bay. 


\section{APPENDIX A}

Calculation for mortality rate of quahog larvae. E.S, early stage larvae; L.S, late stage larvae.

\begin{tabular}{ccc}
\hline & \multicolumn{3}{l}{ LARVAL STAGES } \\
\cline { 2 - 3 } DAY & E.S & L.S \\
\hline 26-May & 573 & 17 \\
31-May & 179 & 12 \\
9-Jun & 2465 & 29 \\
14-Jun & 115 & 11 \\
20-Jun & 6801 & 10 \\
28-Jun & 619 & 20 \\
7-Jul & 963 & 112 \\
13-Jul & 113 & 12 \\
19-Jul & 446 & 41 \\
28-Jul & 318 & 7 \\
4-Aug & 1174 & 6 \\
9-Aug & 44 & 4 \\
14-Aug & 35 & 6 \\
23-Aug & 189 & 9 \\
30-Aug & 111 & 1 \\
\hline
\end{tabular}

Survival rate of cohort-1 $=($ L.S on June $9:$ E.S on May 26) $=29: 573=0.051$ Mortality rate of cohort- $1=1-0.051=0.949$

Survival rate of cohort-2 $=($ L.S on June $14:$ E.S on May 31) $=11: 179=0.062$ Mortality rate of cohort-2 $=1-0.062=0.938$

Survival rate of cohort-13 $=($ L.S on Aug $30:$ E.S on Aug 14) $=1: 35=0.0286$ Mortality rate of cohort- $13=1-0.0286=0.9714$ 


\section{BIBLIOGRAPHY}

Andrews, J.D. 1983. Transport of bivalve larvae in James River, Virginia. Journal of Shellfish Research 3 (1) : 29-40.

Bean, C. 1990. An economic analysis of compliance in the Rhode Island inshore clam fishery. Dissertation. University of Rhode Island. $211 \mathrm{p}$.

Bourne, D.W. and J.J. Govani. 1988. Distribution of fish eggs and larvae and patterns of water circulation in Narragansett Bay, 1972-1973. pp. 132148. In: M.P. Weinstein (ed.). Larval fish and shellfish transport through inlets. American Fisheries Society Symposium 3. Bethesda.

Bricelj, V.M. 1993. Aspects of the biology of the Northern Quahog Mercenaria mercenaria, with emphasis on growth and survival during early life history. pp. 29-48. In: M. A. Rice \& D. Grossman-Garber (eds.). Proceedings of the Second Rhode Island Shellfish Industry Conference. Rhode Island Sea Grant, Univ. of Rhode Island, Narragansett.

Carriker, M.R. 1951. Ecological observation on the distribution of oyster larvae in New Jersey estuaries. Ecological Monograph 21 (1) : 19-38.

1961. Interrelation of functional morphology, behavior, and autecology in early stages of the bivalve Mercenaria mercenaria. Journal of the Mitchell Society pp. 168-241.

Chanley, P. and J.D. Andrews. 1971. Aids for identification of bivalve larvae of Virginia. Malacologia 11 (1) : 45-119.

Chinman, R.A., and S.W. Nixon. 1985. Depth-area-volume relationships in Narragansett Bay. Marine Technical Report 8764 p.

Craig, P.D., and R.J. McLoughlin. 1994. Modeling scallop larvae movement in Great Oyster Bay. pp. 307-325. In P.W. Samarco and M.L. Heron (eds.). The biophysics of marine larval dispersal. American Geophysical Union. Washington, D.C.

Davis, H.C. 1969. Shellfish hatcheries - present and future. Transaction of the American Fisheries Society $4: 743-750$.

Diamond, H. 1981. Life history and environmental adaptation of bivalves as a function of feeding mode. Thesis. University of Rhode Island. $75 \mathrm{p}$. 
Durbin, A. and E. Durbin. 1988. Zooplankton and ichtyoplankton in Narragansett Bay: status and trends, Part 1: Zooplankton. Narragansett Bay Project - USEPA. $26 \mathrm{p}+$ Appendix.

Gordon, R.B. 1982. Wind driven circulation in Narragansett Bay. Dissertation. University of Rhode Island.

Gordon, R.B., and M.L. Spaulding. 1987. Numerical simulations of the tidal and wind-driven circulation in Narragansett Bay. Estuarine, Coastal and Shelf Science 24:611-636.

Haven, D.S., and L.W. Fritz. 1985. Setting of the American Oyster, Crassostrea virginica, in the James River, Virginia : temporal and spatial distribution. Marine Biology $86: 271-282$.

Hess, K.W. 1976. A three dimensional numerical model of the estuary circulation and salinity in Narragansett Bay. Estuarine and Coastal Marine Science 4:325-338.

Hicks, S.D. 1959. The physical oceanography of Narragansett Bay. Limnology and Oceanography 4:316-327.

Hillman, N.S. 1964. Studies on the distribution of decapod larvae in Narragansett Bay, Rhode Island, with consideration of morphology and mortality. Thesis. University of Rhode Island. $74 \mathrm{p}$.

Ippen, A.T. 1966. Estuaries of rectangular section. pp. 493-522. In A.T. Ippen (ed.). Estuary and coastline hydrodynamics. McGraw-Hill Book Co., Inc. New York.

Johnson, R.A., and G.K. Bhattacharya. 1992. Statistics : principles and methods. Second Edition. John Wiley \& Sons, Inc. New York. 686 p.

Jones, D.D., M.A. Arthur, and D.J. Allard. 1989. Schlerochronological records of temperature and growth from shells of Mercenaria mercenaria from Narragansett Bay, Rhode Island. Marine Biology 102: 225-234.

Ketchum, B.H. 1954. Relation between circulation and planktonic population in estuaries. Ecology 35(2) : 191-200.

Korringa, P. 1947. Relations between the moon and periodicity in the breeding of marine animals. Ecological Monograph 17(3) : 349-381. 
Kremer, J.N. 1975. Analysis of a plankton-based temperate ecosystem : an ecological simulation model of Narragansett Bay. Dissertation. University of Rhode Island. $369 \mathrm{p}$.

Kunkle, D. E. 1958. The Vertical distribution of oyster larvae in Delaware Bay. Proceeding of the National Shellfisheries Association 48 : 90-91.

Landers, W.S. 1954. Seasonal abundance of clam larvae in Rhode Island waters, 1950-1952. U.S. Fish and Wildlife Service 117:1-29.

. 1955. Notes on the predation of the hard clam, V. mercenaria, by the mud crab, Neopanope texana. Ecologv 35(3) : 422.

Lazar, N., A. Ganz, and A. Valliere. 1995. Quahog stock assessment and implementation of an interim management plan in Greenwich Bay, Rhode Island. pp : 5-29. In M.A. Rice and D. Grossman-Garber (eds.). Proceedings of the third Rhode Island Shellfish Industry Conference. Rhode Island Sea Grant, University of Rhode Island, Narragansett, R.I.

Levine, E.R., and K.E. Kenyon. 1975. The tidal energetics of Narragansett Bay. Journal of Geological Research 80:1683-1688.

Loosanoff, V.L. 1937a. Development of the primary gonad and sexual phases in Venus mercenaria. Biological Bulletin 72(3) : 389-405.

. 1937b. Seasonal gonadal changes of adult clams. Biological Bulletin 72(3) : 406-416.

Loosanoff, V.L. and H.C. Davis. 1950. Conditioning of Venus mercenaria for spawning in winter and breeding its larvae in the laboratory. Biological Bulletin $98: 60-65$.

Loosanoff, V.L. and C.A. Nomejko. 1951. Spawning and setting of the American oyster, $O$. virginica, in relation to lunar phases. Ecology $32(1)$ :113-134.

Loosanoff, V.L., H.C. Davis and P.E. Chanley. 1966. Dimensions and shapes of larvae of some marine bivalve mollusks. Malacologia 4 (2) : 351435.

Manning, J.H. and H.H. Whaley. 1954. Distribution of oyster larvae and spat in relation to some environmental factors in a tidal estuary. Proceeding of the National Shellfisheries Association $45: 56-65$. 
McConaugha, J.R. 1985. Nutrition and larval growth. pp: 127-154. In A.M. Werner (ed.). Crustacean issues 2 : larval growth. A.A. Balkema. Boston.

1988. Export and reinvasion of larvae as regulators of estuarine decapod populations. pp. 90-103. In M.P. Weinstein (ed.). Larval fish and shellfish transport through inlets. American Fishery Society Symposium. 3.

Menzel, W. 1989. The biology, fishery and culture of quahog calms, Mercenaria. pp : 201-242. In J.J. Manzi and M. Castagna (eds.). Clam mariculture in North America. Elsevier, New York.

Nelson, T.C. 1955. Observation of the behavior and distribution of Oyster Larvae. Proceeding of the National Shellfisheries Association $45: 23$ 28.

Nelson, W.G. 1987. The physiology and reproductive ecology of the Mussel, Mytilus edulis L. from Two Locations in Narragansett Bay. Dissertation. $153 \mathrm{p}$.

Okubo, A. 1980. Diffusion and ecological problems : mathematical models. Springer-Verlag. New York. $254 \mathrm{p}$.

. 1994. The role of diffusion and related physical processes in dispersal and recruitment of marine populations. pp. 3-32. In P.W. Samarco and M.L. Heron (eds.). The biophysics of marine larval dispersal. American Geophysical Union. Washington, DC.

Perkins, E.J. 1974. The biology of estuaries and coastal waters. Academic Press. New York. $678 \mathrm{p}$.

Pilson, M.E.Q. 1985. On the residence time of water in Narragansett Bay. Estuaries 8:2-14.

Pratt, S.D. 1988. Status of the hard clam fishery in Narragansett Bay. Narragansett Bay Project - USEPA. 89 p.

Rice, M.A. 1992. The Northern Quahog : The biology of Mercenaria mercenaria. Rhode Island Sea Grant, University of Rhode Island, Narragansett, R.I. 59p.

1993. Overview of quahog management studies in Narragansett Bay 1946 to 1992. pp. 49-61. In: M. A. Rice \& D. Grossman-Garber (eds.). Proceedings of the Second Rhode Island Shellfish Industry 
Conference. Rhode Island Sea Grant, Univ. of Rhode Island, Narragansett.

Rice, M.A. 1996. The 1995 status of the shellfisheries for the Northern Quahog, Mercenaria mercenaria, in New England. Abstract. Journal of Shellfish Research. 15(2): 481.

Rice, M.A. C. Hickox, and I. Zehra. 1989. Effect of intensive fishing effort on the population structure of quahogs, Mercenaria mercenaria, in Narragansett Bay. Journal of Shellfish Research $8: 345-354$.

Rice, M.A. and J. Goncalo. 1995. Results of a study of bivalve larval abundance in Greenwich Bay, Rhode Island. pp. 31-40 In: Rice, M.A. and M.L. Schwartz (eds.). Proceedings of the 3rd Biannual Rhode Island Shellfish Industry Conference. Rhode Island Sea Grant, University of Rhode Island, Narragansett.

Royce, W.F. 1984. Introduction to the practice of fishery science. Academic Press, Inc. San Diego. 428 p.

Saila, S.B., J.M. Flowers, and M.T. Canario. 1967. Factors affecting the relative abundance of Mercenaria mercenaria in the Providence River, Rhode Island. Proceeding of the National Shellfisheries Association 57 : 83-89.

Sandifer, P.A. 1975. The role of pelagic larvae in recruitment to populations of adult decapod crustaceans in the York River estuary and adjacent lower Chesapeake Bay, Virginia. Estuarine and Coastal Marine Science 3: 269279.

Sastry, A.N. 1983. Pelagic larval ecology and development. pp;213-282. In F.J. Vernberg and W.B. Vernberg (eds.). The biology of crustacea : behavior and ecology. Academic Press. New York.

Scheltema, R.S. 1986. On dispersal and planktonic larvae of benthic invertebrates : an eclectic overview and summary of problems. Bulletin of Marine Science 39(2) : 290-322.

Seliger, H.H., Boggs, J.A., Rivkin, R.B., Biggley, W.H., and Aspden, K.R.H. 1982. The Transport of oyster larvae in an estuary. Marine Biology 71 : $57-72$.

Smayda, T.J. 1988. Environmental conditions and plankton dynamics in Narragansett Bay during an annual cycle characterized by a brown tide. Narragansett Bay Project - USEPA. $89 \mathrm{p}$. 
Sparsis, M., J.T. DeAlteris, and M.A. Rice. 1993. Effects of bottom cultivation on quahogs and other bottom invertebrates in Narragansett Bay. pp. 6378. In: M. A. Rice \& D. Grossman-Garber (eds.). Proceedings of the Second Rhode Island Shellfish Industry Conference. Rhode Island Sea Grant, Univ. of Rhode Island, Narragansett.

Spaulding, M. 1987 Circulation dynamics in Narragansett Bay pp. 71-146. In Issues, Resources, Status, and Management. Proceeding of a Seminar, NOAA Estuary of the Month Seminar Series no. 1. Washington, D.C.

Spaulding, M., Swanson, C., and Turner, C. 1990. The new tides and tidal currents of Narragansett Bay. Rhode Island Sea Grant. University of Rhode Island Marine Technical Report. 39p.

Stickney, A.P. and L.D. Stringer. 1957. A study of the invertebrate bottom fauna of Greenwich Bay, Rhode Island. Ecology 38 : 11-122.

Stoner, A.W., R.A. Glazer, and P.J. Barile. 1996. Larval supply to queen conch nurseries : relationships with recruitment process and population size in Florida and the Bahamas. Journal of Shellfish Research 15(2) : 407-420.

Tett, P.B. 1987. Plankton. pp:280-341. In : J.M. Baker and W.J. Wolff (eds.). Estuarine and brackish-water sciences association handbook : biological surveys of estuaries and coasts. Cambridge University Press. Cambridge.

Trifan, D. 1987. Depth distribution of Narragansett Bay decapod larvae and the ontogeny of behavioral responses to gravity, light, hydrostatic pressure, and current in Neopanope sayi (Smith). Dissertation. University of Rhode Island. $214 \mathrm{p}$.

Turner, A.C. 1984. Tidal and subtidal circulation in the Providence River. Thesis. University of Rhode Island. $285 \mathrm{p}$.

Turner, A.C. , S. Pucket, T. Isaji, S. Feng. 1991a. Providence River wet weather dye study data report. Narragansett Bay Project - USEPA. 85 p.

1991b. Providence River wet weather current meter study data report. Narragansett Bay Project USEPA. 27 p. + appendix. 
Wood, L. and W.J. Hargis. 1971. Transport of bivalve larvae in a tidal estuary. pp. 29-53. In D.J. Crips (ed.). Fourth European Marine Biology Symposium. Cambridge University Press. Cambridge. 